Alice Mabel Prates Monteiro

\title{
A Contribuição do Discurso Histórico Escolar no Processo de Construção das Identidades dos Estudantes
}

Monografia apresentada à Graduação em História da PUC-Rio como requisito parcial para a obtenção do título licenciatura em História.

Orientadora: Prof ${ }^{a}$ lamara da Silva Viana

Rio de Janeiro

Novembro de 2018 
À minha mãe,

que foi sempre fênix. 


\section{Agradecimentos}

Esta pesquisa monográfica, mais do que um consistente trabalho, representa a conclusão de um ciclo: a graduação. Acredito que nada na vida seja uma conquista inteiramente individual, pois estamos sempre cercados de pessoas que nos ajudam e nos dão o suporte necessário para avançar. Nesses 5 anos na faculdade de história, seres humanos incríveis fizeram parte desse meu caminho, que agora devo trilhar profissionalmente. A elas, o meu eterno afeto!

Agradeço em primeiro lugar à minha mãe, Deborah Prates, por ser minha base, meu porto seguro, minha família, meu ícone feminista. Durante todos os meus anos de vida, o incentivo ao estudo sempre foi presente em minha casa e isso com certeza influenciou a pessoa que sou hoje. Por seu espírito forte, que me ensinou a enfrentar os desafios da vida de cabeça erguida, por sua dedicação e ternura, que me alimentaram o coração, por sua incansável batalha contra todas as inacessibilidades e por ser uma ininterrupta fonte de admiração e aprendizado, essa conquista é também dela. Não tenho nenhuma sombra de dúvida ao afirmar a sorte que tive de possuir uma mãe fantástica e uma ótima criação.

Agradeço, em segundo lugar, a instituição PUC-Rio, pela excelência de seu corpo docente, administração, funcionários e instalações. Como bolsista, esse sonho não teria sido possível sem essa humana oportunidade. Foi um prazer enorme poder participar da história dessa universidade, que não apresenta nada menos do que se propõe. Sempre guardarei a PUC-Rio com muito carinho no coração.

Em especial, quero registrar meus mais sinceros agradecimentos ao departamento de História, que tornou essa graduação muito mais feliz e nostálgica. Ao professor Ilmar Rohloff de Mattos, por acreditar em mim e me mostrar as maravilhas e responsabilidades do trabalho docente; à minha orientadora e amiga professora Iamara da Silva Viana, por me acolher de forma tão carinhosa e entender, por semelhança, a loucura da minha vida no final da graduação. Obrigada por todos os nossos papos! Também agradeço à professora e atual diretora do departamento Maria Elisa Noronha de Sá, por ser essa profissional exemplar e dedicada, que nos inspira a cada dia. E, finalmente, a todos os funcionários que diariamente nos cumprimentam com um sorriso que nos transmite aquela sensação gostosa de estar em casa, além de claro com bastante café e biscoitinhos, essenciais na vida de 
qualquer universitário. Obrigada Cláudio, Cleusa, Moisés, Igor e Anair, vocês são mil! Sentirei saudades.

Agradeço aos meus amigos de toda a vida Júlia (Zuzu), Isabella (Zazá) e João Vitor (Joenes) por todo o carinho e verdadeiro amor que compartilharam comigo durante os melhores e piores momentos; por serem a definição mais clara de "eu estou aqui com você, pode contar comigo" que eu já tive a sorte de compreender e experienciar. Meus amigos do coração, família que eu construí, muito obrigada por caminharem junto comigo; minha vida não seria a mesma sem vocês.

Agradeço também ao meu namorado Guilherme (Gui) por ouvir todas as minhas reclamações, compreender minha falta de tempo e vida maluca e, mesmo durante o caos, me oferecer carinho e aconchego. Obrigada pelas trocas e aprendizados que tivemos a linda oportunidade de experimentar até agora. Se existe algo que eu possa pedir ao destino é que minha vida continue correndo junto a sua. Amo você, minha fusão.

Agradeço ainda aos meus amigos de estágio do Palácio Tiradentes, que ao longo desse último ano estiveram comigo compartilhando os mesmos perrengues de graduação e o mesmo palácio. Obrigada pela camaradagem nas visitas guiadas, pelos abraços trocados e os conselhos dados, pelas vibrações positivas e comemorações de conquista e por fim, obrigada por repetirem todos os dias comigo "Bem-vindos ao Palácio Tiradentes: sede da Assembleia Legislativa do Estado do Rio de Janeiro".

Por último, mas definitivamente não menos importante, agradeço as minhas amigas e companheiras de jornada Isabela (Bels), Maria Alice (Malice), Carolina (Carol) e Ana Amélia (Bey), por viverem comigo tantos bons momentos e terem me proporcionado uma experiência universitária verdadeiramente incrível. Musas da minha vida, tão generosas de coração, obrigada pelas risadas, conversas, desabafos (não foram poucos) e lágrimas trocadas; obrigada pelos intervalos do café no departamento, pelos encontros no falecido Gourmet, pelas vilas dançadas e pelos abraços trocados às pressas no corredor no meio da correria do dia. Vocês fizeram toda a diferença! 


\section{Resumo:}

Esta pesquisa tem por objetivo evidenciar a relação entre a forma como o discurso histórico escolar é elaborado pelos professores em sala de aula e a construção identitária dos discentes. Para isso, compreende-se o conceito de representação como elemento chave nos processos de identificação, subjetivação e incorporação ativa do imaginário social presente na realidade brasileira. Partindo da perspectiva teórica proporcionada pela Nova História Cultural, aliada aos estudos sobre o ensino de história, é intenção salientar o potencial performativo do discurso, bem como frisar o compromisso educacional de constante combate às desigualdades sociais. Para isso, a proposta apresentada no presente trabalho baseia-se na formulação e aplicação de uma narrativa histórica descentrada, denominada "multiculturalismo performativo", capaz de fornecer subsídios para uma reflexão crítica pelos discentes acerca da realidade e abrir, assim, possibilidades para atitudes transformadoras.

\section{Palavras-chave:}

Discurso histórico escolar, Representação, Identidade, Multiculturalismo 


\section{Abstract}

This research aims to point out the relation between the way how schools' historical discourses are elaborated by teachers in classroom and the formation of identity of the student body. In this, the concept of representation is considered a key element in the processes of identification, subjectivation and active incorporation of the social imaginary present in Brazilian reality. Starting from the theoretic perspective proportioned by the New Cultural History, summed with studies on history teaching, the main intention is to accentuate the performance potential of discourse as well as emphasize the commitment of education to constantly fight social inequality. For this, the proposal is based in the formulation and execution of an uncentered historical narrative denominated "performative multiculturalism", capable of providing means for a critical reflection by students about reality and, thus, opening possibilities for changes in behavior.

\section{Keywords:}

School's historical discourse, Representation, Identity, Multiculturalism 


\section{Sumário}

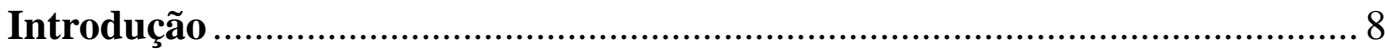

Capítulo 1: O Discurso Histórico Escolar ...................................................... 13

1.1 Teoria Social-Cultural do Discurso ........................................................ 13

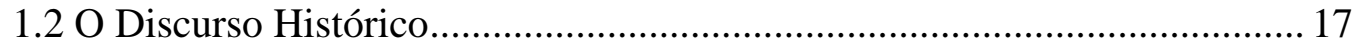

1.3 O Discurso Histórico Escolar .................................................................... 23

Capítulo 2: A Construção Social das Identidades e Diferenças ...................... 30

2.1 Identidade e Diferença: Conceitos Relacionais .......................................... 30

2.2 Como as Identidades e Diferenças São Construídas? .................................. 31

2.3 Crise de Identidade: Identidades Fragmentadas ........................................ 35

2.4 Identidade Nacional e Globalização ........................................................ 39

2.5 Entre Fixação e Fluidez: As Disputas Relacionais de Poder ....................... 41

Capítulo 3: História, Memória e Multiculturalismo Performativo ………….... 47

3.1 O Passado Como Elemento Chave na Formação da Cultura Política

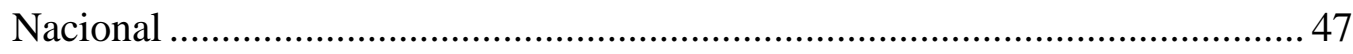

3.2 Memória Passada e Projeto Futuro .......................................................... 51

3.3 Multiculturalismo Performativo ............................................................ 54

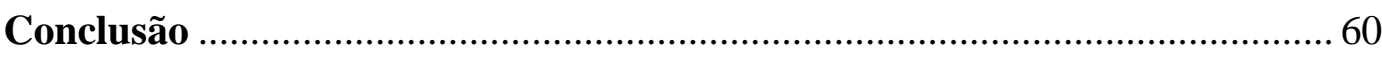

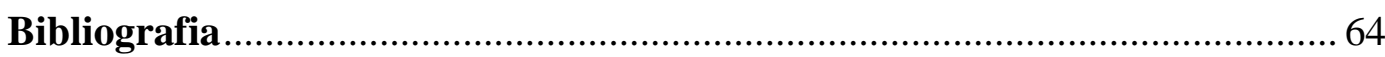




\section{Introdução}

É por meio da observação do meio social que o historiador retira as inquietações que lhe servem de ponto de partida para a pesquisa acadêmica. Nesse sentido, o Brasil é um país plural, desigual e de dimensão continental; sendo essas características também presentes na educação, entendida como rede de experiências e ensinamentos essenciais para a inserção e atuação plena do indivíduo nos espaços sociais e políticos da sociedade ${ }^{1}$.

A Educação Básica se configura, assim, como dimensão fundante da cidadania por meio do processo de percepção e posterior corroboração ou contestação da realidade, constituindo-se em principal momento de sociabilidade, reflexão e formação de subjetividades das crianças e adolescentes ${ }^{2}$. Não diferentemente da esfera macrossocial, o ambiente escolar abriga múltiplas vozes e é estruturado por relações de poder, que vão desde a relação entre alunos, até a conexão desses com o quadro de professores(as), funcionários(as) e pela comunidade ao redor.

É nesse espaço de sociabilidade, compartilhado pela maioria esmagadora das crianças e jovens brasileiros, onde constrói-se, transforma-se e experiencia-se o amplo rol de identidades e diferenças presentes no tecido social. Em momento nenhum é minha pretensão neste trabalho afirmar que o ambiente escolar seja o único espaço no qual convive-se e partilha-se a diferença, sendo mais um no universo de interações e influências mútuas vivenciadas pelos indivíduos ao longo de suas existências.

Destaco a passagem de Vasco Pedro Moretto, na introdução de seu livro intitulado Construtivismo: a produção do conhecimento em aula, pois corroboro com sua visão sobre a função da escola como detentora de papel social tanto conservador quanto transformador:

Conservador porque a ela cabe propor às novas gerações os conhecimentos construídos ao longo da história humana. Nesse processo, a escola exerce um papel fundamental ao selecionar criteriosamente, entre todos os conhecimentos

\footnotetext{
${ }^{1}$ Art. 205 da Constituição Federal de 1988: “A educação, direito de todos e dever do Estado e da família, será promovida e incentivada com a colaboração da sociedade, visando ao pleno desenvolvimento da pessoa, seu preparo para o exercício da cidadania e sua qualificação para o trabalho".

2 Diretrizes Curriculares Nacionais da Educação Básica. Disponível em <http://portal.mec.gov.br/index.php?option=com_docman\&view=download\&alias=13448diretrizes-curiculares-nacionais-2013-pdf\&Itemid=30192>. Acesso em 11 jun. 2018.
} 
desenvolvidos, aqueles relevantes para a iniciação dos jovens no mundo social. Ao mesmo tempo, exerce seu papel transformador ao preparar criticamente os jovens, capacitando-os a analisar sua sociedade, avaliar as relações existentes, equacionar seus problemas e propor transformações (Moretto, 2003, p. 90-91).

Enfatizo, neste trabalho monográfico, a luz do exposto, o espaço da sala de aula como lugar particular de troca e compartilhamento dos conhecimento e vivências pessoais. A aula de História é pensada, então, como momento propício e fundamental para refletir-se a respeito da nossa experiência como humanos e cidadãos, pois é vivida e escrita no tecer conflituoso das relações sociais. O discurso histórico escolar, nela produzido, serve, assim, como parâmetro autenticador da realidade social presente.

Nesse contexto, é justamente na relação de papeis conservadores e transformadores, ao longo da prática educacional cotidiana, que os estereótipos socioculturais, tais como de gênero e étnico-raciais, são frequentemente edificados e reproduzidos. No contraponto, o ambiente escolar pode se apresentar também como lugar político e campo privilegiado de discussão, com capacidade para ser um foco contra-hegemônico e democrático, já que da mesma forma que visa contribuir para a inserção dos jovens na sociedade, também sofre influência desta a todo momento.

Esses valores identitários positivos e negativos são formulados por meio de representações, matéria-prima no processo de solidificação subjetiva das imagens produzidas socialmente sobre a visão de si do indivíduo ${ }^{3}$. Essas representações, que podem ser entendidas como parte de um imaginário social de apreensão e compreensão do mundo, podem ou não ganhar força no meio social e se tornarem expressão da realidade social. Sua ausência, ou presenta parcial, nesse sentido, também colabora para a formação de uma autoimagem negativa dos estudantes.

Em particular, chamou-me atenção, desde a época de aluna da Educação Básica, a falta de presença feminina nas narrativas históricas construídas pelos professores através do discurso formulado em sala de aula. Quando as mulheres apareciam finalmente, eram quase sempre representadas em papeis sociais coadjuvantes, tais como mãe, esposa ou amante.

Ao longo de minha formação nunca ouvi falar de Maria Quitéria, Nísia Floresta, Carolina de Jesus ou Bertha Lutz, para citar alguns exemplos de mulheres

\footnotetext{
${ }^{3}$ Baseio-me nos estudos de Silva e Hall, discutidos de forma mais aprofundada no capítulo 2 do presente trabalho.
} 
que desenvolveram contribuições relevantes para a História do Brasil. Por outro lado, não é pequena a lista de homens que estudamos para a disciplina, os quais não vale aqui citar. No entanto, entre os próprios homens, silencia-se constantemente do discurso histórico escolar características de raça quando o assunto não diz respeito diretamente à instituição da escravidão. Foi somente na graduação, por exemplo, que descobri que Machado de Assis e André Rebouças eram pessoas negras.

Temos a consciência, em 2018, que os grupos marginalizados ${ }^{4}$, ou seja, aqueles que carregam marcadores sociais negativos, nos quais as mulheres e os negros se encaixam, são constantemente omitidos do discurso ou relegados a segundo plano, a título de "curiosidade" e difundidos em situações estereotipadas, o que corrobora para a conformação e consequente manutenção do status quo.

Como consequência desse quadro, gerou-se uma espécie de baixa autoestima coletiva em todos eles, que são vistos e se veem como inferiores ou incapazes. Acredito ser esse sentimento fruto de uma construção histórica, mantida e reforçada também na forma pela qual as representações sociais são elaboradas no discurso histórico nas salas de aula brasileiras; elas são reproduzidas de forma incompleta e deturpada em razão da falta de uma abordagem crítica, que evidencie que o processo de exclusão é histórico, e nunca biológico.

É, portanto, intenção desta pesquisa evidenciar que a forma como o discurso histórico escolar é elaborado em sala de aula, por meio das representações dos atores sociais, interfere no processo de construção das identidades dos discentes. É dever ético dos professores, portanto, formular uma narrativa histórica justa, colocando os sujeitos, em suas multiplicidades, como pessoas inteiras e, assim, adotando uma postura atitudinal em direção à diminuição das desigualdades e preconceitos sociais.

O presente trabalho é calcado nas possibilidades abertas pela corrente historiográfica da Nova História Cultural ${ }^{5}$, que não somente garantiu maior

\footnotetext{
${ }^{4}$ Segundo as Diretrizes Curriculares Nacionais da Educação Básica, p. 18, constituídos por "pobres, mulheres, afrodescentendes, indígenas, pessoas com deficiência, as populações do campo, os de diferentes orientações sexuais, os sujeitos albergados, aqueles em situação de rua, em privação de liberdade".

${ }^{5}$ Para saber mais ver GOUVÊA, M. De F.; BICALHO, M. F. B.; SOIHET, R. Culturas políticas: ensaio de história cultural, história política e ensino de história. Rio de Janeiro: FAPERJ: Mauad, 2005.
} 
visibilidade e autonomia aos grupos sociais vulneráveis, como também fomentou novas pesquisas sobre o ensino de História. Essa abertura caracterizou importante ferramenta de reflexão para construirmos uma sociedade cada mais inclusiva e democrática.

Reconhecendo a importância de estudar sobre a formação dos currículos formais e informais, creio que já existam números razoáveis de trabalhos sobre o assunto. Não é minha intenção, portanto, me alongar sobre este tópico, situando essa pesquisa monográfica como uma contribuição diferente, agregadora e complementar ao assunto, visando a constante melhoria do nosso ensino.

No entanto, é pertinente ressaltar o progresso institucional referente a criação da Lei 10.639/2003, que incluiu no currículo oficial da Rede de Ensino a obrigatoriedade da temática "História e Cultura Afro-Brasileira", além de dar outras providências, o que foi marco reconhecido entre os pesquisadores educacionais de um avanço na direção da democratização do ensino.

Além disso, também vale destacar os Temas Transversais dos Parâmetros Curriculares Nacionais (1998), dentre eles a seção de Pluralidade Cultural; bem como as Diretrizes Curriculares Nacionais Gerais da Educação Básica (2013), do Ministério da Educação em parceria com a Secretária de Educação Básica, cujo subtítulo Diversidade e Inclusão, dentre seus objetivos gerais, busca justamente atuar sobre as representatividades sociais na educação, a luz dos novos parâmetros sociais contemporâneos.

A pesquisa se divide em três capítulos. No capítulo 1 discorro a respeito do discurso histórico escolar, inserindo-o numa perspectiva interdisciplinar, destacando as mudanças históricas relativas à sua produção e evidenciando as peculiaridades do ambiente escolar no processo de sua formulação dentro da sala de aula. No capítulo 2 analiso como se realiza a construção das identidades, correlacionando-as de forma inseparável ao conceito de diferença. Reflito ainda sobre a importância das representações nos processos de identificação e subjetivação e sua relação com o conceito de performatividade ${ }^{6}$, bem como sobre a fragmentação identitária em função da pós-modernidade e sua interferência na dinâmica das hierarquias sociais.

\footnotetext{
${ }^{6}$ Silva (2000), utilizando o conceito expandido por Judith Butler.
} 
Já no capítulo 3, abordo como o discurso histórico escolar colabora para a edificação de uma memória individual e coletiva, que atua no processo de construção das visões identitárias dos discente na contemporaneidade. Por fim, aposto na prática do descentramento da História, amparada nos estudos teóricos de Natalie Davis, como ferramenta para a instauração de um ensino multicultural, o qual possa reconhecer as diferentes identidades de forma justa, sem, entretanto, anular as esferas de poder sociais que atuam sobre elas e acabar corroborando para um ensino conformativo. Acredito, ao fim e ao cabo desta introdução, que são os ideais de movimento, luta, transformação e otimismo que alimentam e sustentam esta pesquisa monográfica. 


\section{Capítulo 1: O Discurso Histórico Escolar}

\subsection{Teoria Social-Cultural do Discurso}

O processo de contribuição e interdisciplinaridade entre as ciências sociais vem, nas últimas décadas, graças ao fortalecimento da Nova História Cultural, proporcionando valiosas interpretações referentes ao estudo da cultura, oferecendo novas chaves de leitura para as experiências humanas ao longo do tempo. Enfatizo aqui a relação entre antropologia e história protagonizada pelo antropólogo Marshall Sahlins, em seu livro "Ilhas de história"7.

Sahlins se coloca contra o binarismo presente no estudo do conceito de cultura ao afirmar que estrutura simbólica e prática social são termos dialéticos; entendendo, pois, por estrutura simbólica o sistema de categorias gerais pautado cognitivamente por um mecanismo linguístico, que determina valores e padrões de coerência e reconhecimento. Já por prática social, compreende as ações e experiências humanas contingencialmente vivenciadas em comunidade ${ }^{8}$.

As pessoas, em suas vidas cotidianas e com interesses, experiências e biografias sociais diversas, organizam seus projetos e dão sentido à materialidade a sua volta partindo de concepções linguísticas preexistentes, que são compartilhadas pela comunidade. A palavra, assim, nunca é vazia, ela está carregada de conteúdos simbólicos. Assim, toda ação prática, intencional e atrás de reconhecimento, utiliza o sistema cultural de símbolos e significados para atingir o seu objetivo perante a comunidade 9 .

Por outro lado, o sistema simbólico é a todo momento tensionado e colocado em risco pela realidade, por meio das ações de cada indivíduo nas suas formas particulares de existência e no seu potencial criativo. As pessoas, em sua vida ordinária, repensam seus esquemas simbólicos convencionais frente as contingências, que não se guiam pelas vontades ou interpretações específicas de determinado grupo, atribuindo novos sentidos e significados a velhos símbolos.

\footnotetext{
${ }^{7}$ SAHLINS, Marshall. Ilhas de História. Rio de Janeiro: Jorge Zahar Editor, 1990.

${ }^{8}$ Sahlins, 1987, p. 9.

${ }^{9}$ Sobre essa ideia, ver SAHLINS, Marshall. Estrutura e História. In: de Janeiro: Jorge Zahar Editor, 1990. . Ilhas de História. Rio
} 
Essas atitudes, se atingem um patamar coletivo, têm força para alterar as relações simbólicas e ocasionar uma mudança sistêmica.

Para Sahlins, nesse sentido, portanto, a cultura é historicamente reproduzida na ação (Sahlins, 1987, p. 7); sua perpetuação é garantida pelas próprias transformações internas, posto se adaptarem às novas contingências externas. Ele coloca a estrutura simbólica como objeto histórico ao alegar que uma ação ou acontecimento só se torna um evento, ou seja, só adquire importância social e histórica, se tiver sido legitimado pela estrutura semiótica vigente. Isso significa que, se a cultura é histórica, cada sociedade possui modos particulares de se relacionar com e de escrever seu passado.

O trabalho do historiador é justamente o da interpretação e construção de uma narrativa sobre um acontecimento em sua relação com a estrutura, com o conjunto de símbolos e significados que o sustentam e o legitimam frente a determinada sociedade em um determinado período de tempo. Sobre isso, o filósofo Foucault afirma: "A história, como é praticada hoje, não se desvia dos acontecimentos; ao contrário, alarga sem cessar o campo dos mesmos; aí descobre, sem cessar, novas camadas, mais superficiais ou mais profundas; [...]" (FOUCAULT, 2014, p. 52).

Esse pensamento de Foucault nos ajuda a vislumbrar o caráter social da história. Ele se refere à recente ruptura com o fazer histórico de cunho estruturalista, principalmente relacionado à corrente marxista, que conferia a subordinação dos acontecimentos em prol de uma estrutura englobante. Foucault defende, assim, uma historiografia que coloque em diálogo prática social e estrutura simbólica, na qual os acontecimentos consigam sempre gerar novas interpretações e construções narrativas; ideia essa corroborada pelo presente trabalho. É a análise do que Sahlins chama de estrutura da conjuntura, um agrupamento de relações históricas que simultaneamente reproduzem e transformam categorias culturais, levando em conta suas diacronias internas, ou seja, suas características de mutação, conflito e incoerência, sempre presentes nas diversas realidades.

A historiadora Rachel Soihet e o Núcleo de Pesquisas em História Cultural (Nupehc) conferiram a esse processo de estrutura da conjuntura a nomenclatura de cultura histórica, adotada primeiramente por Bernard Guenée em seu livro História 
e cultura histórica no Ocidente Medieval e que será utilizada ao longo deste trabalho monográfico. ${ }^{10}$

Em outros termos, rompendo-se com as interpretações da cultura como algo homogêneo, universal e imutável, a noção de cultura histórica tem permitido pensar os fenômenos culturais em função de sua historicidade, ou ainda, de suas relações com a temporalidade e com os conflitos sociais (GONTIJO, 2007, p. 15).

Busquei introduzir esse conceito de cultura para situá-lo dentro de uma estrutura dual, de cunho semiótico/simbólico e social/atitudinal. Como sistema linguístico e acontecimento social, o conceito de cultura - e sua relação com a história - está intimamente conectado com o de discurso. Os estudos de Norman Fairclough, que entende este termo como prática social de construção de significado ${ }^{11}$, trazem relevantes contribuições para o presente trabalho monográfico. Isso, pois o linguista compreende discurso como uma forma de agir no âmbito social - ação e representação -, já que é através dele que as pessoas interagem entre si e com o mundo. Ele é síntese indissociável dessa relação dual e simultânea entre estrutura simbólica e experiências sociais.

Um dos fundadores da análise crítica do discurso, modelo teóricometodológico situado entre o campo da linguística e da ciência social crítica, que busca analisar a conexão entre relações de poder e recursos linguísticos, ele afirma que mais do que este último atributo, o discurso envolve aspectos vivos da realidade, conferindo significados ao mundo e às práticas e relações sociais. Segundo o autor,

O discurso contribui para a constituição de todas as dimensões da estrutura social que, direta ou indiretamente, o moldam e o restringem: suas próprias normas e convenções, como também relações, identidades e instituições que lhe são adjacentes. O discurso é uma prática, não apenas de representação do mundo, mas de significação do mundo, constituindo e construindo o mundo em significado (FAIRCLOUGH, 2001, p.91).

Fairclough confere três efeitos construtivos ao discurso: ele contribui para a construção das identidades sociais, das relações sociais entre as pessoas e dos sistemas de conhecimento e crença. Particularmente, é sobre o primeiro efeito que esta pesquisa se edifica, traçando relações de influência com o segundo e o terceiro, associados aqui ao ambiente escolar e ao conhecimento histórico, respectivamente.

\footnotetext{
${ }^{10}$ Tradução livre. No original Histoire et culture historique dans l'Occident medieval.

${ }^{11}$ Ver FAIRCLOUGH, Norman; MAGALHÃES, Izabel. Discurso e mudança social. Brasília, DF: Ed. Universidade de Brasília, 2001.
} 
A construção de significados nessa estrutura ocorre por meio de um embate de múltiplas vozes, permeadas por relações de poder, dentro de um contexto social, histórico e cultural amplos. Nesse sentido, estudar o discurso implica analisar como os sujeitos que o detém, ou não, se constroem e edificam sua realidade.

Michel Foucault fez uma importante contribuição acerca dessas relações de poder discursivas como prática social. Segundo o autor, são elas que irão ditar quais os sujeitos detentores de fala, em que circunstâncias e como os participantes, sejam possuidores de palavra ou não, podem interagir uns com os outros. Todo discurso, mas aqui enfatizo aqueles legitimadores e estruturantes, ou seja, aqueles reconhecidos como verdade, possui mecanismos de dominação e criação que variam de sociedade para sociedade, posto que estão relacionados histórica e culturalmente.

No entanto, "o discurso não é simplesmente aquilo que traduz as lutas ou os sistemas de dominação, mas aquilo porque, pelo que se luta, o poder do qual nos queremos apoderar” (FOUCAULT, 2014, p. 10). O direito à voz, nesse contexto, é uma batalha contemporânea dos grupos sociais vulneráveis, que se manifesta por meio de táticas de resistência discursiva - contra-discursos - e ressignificação de conceitos.

Isso se dá porque o poder social carregado por qualquer discurso é responsável pela construção e reconstrução de significados no mundo; significados esses que podem incluir hierarquias de valor ao apresentarem benefícios identitários e materiais para aqueles em sua posse e consequentemente malefícios aos subjugados por ele. Nessa lógica, ter poder social é correlato a ser reconhecido.

Memórias seletivas e leituras do passado atribuem significados positivos e/ou negativos a períodos, acontecimentos, personagens, obras, etc. Tais leituras e enquadramentos de memórias permitem associar uma dada cultura política a uma determinada cultura histórica, compreendendo esta última como o modo como uma sociedade - ou uma parte dela - lida com seu passado (GONTIJO, 2007, p.15).

De forma concreta, o conteúdo da fala ou da escrita de determinado sujeito pode ser acatado pela sociedade com mais ou menos pretensão de verdade, dependendo do grupo social ao qual esse sujeito se identifica ou é identificado pelos demais. A estrutura simbólica que agrega os conceitos classe social, raça, gênero, sexualidade, deficiência, profisssão, religião, idade, nacionalidade, nível educacional, etc., constrói relações de poder de maior ou menor grau entre o sujeito 
que fala e seu interlocutor, afetando sua recepção e reconhecimento pela sociedade. O discurso é, assim, sempre contextualizado cultural e historicamente.

É importante ressaltar, no entanto, que essas relações de poder hierárquicas não são estáticas; elas mudam e se transformam face às ações humanas de resistência, sejam sutis ou poderosas, em uma relação onde as experiências não sejam subestimadas em prol de um conceito estruturante, mas que também não se menospreze o poder do discurso enquanto ferramenta de controle social.

O discurso histórico, como um tipo de discurso, abrange todas as características acima elencadas. Ele tem, portanto, papel fundamental na perpetuação ou transformação das relações de poder contemporâneas. O objetivo desta primeira análise é que a partir do esclarecimento dos mecanismos de funcionamento e de dominação das práticas sociais discursivas, seja possível a desarticulação e desconstrução dessas estruturas em prol de outras, mais democráticas e colaborativas.

\subsection{O Discurso Histórico}

O discurso histórico é resultado do conhecimento produzido e organizado em uma disciplina. Para Foucault, disciplina "se define por um domínio de objetos, um conjunto de métodos, um corpus de proposições consideradas verdadeiras, um jogo de regras e de definições, de técnicas e de instrumentos [...]" (FOUCAULT, 2014, p. 28). Essas limitações sobre a forma de produção do conhecimento histórico servem como procedimento de controle do discurso, no qual uma categoria de profissionais - os historiadores - ditam as interpretações que serão reconhecidas socialmente como verdade.

Isso acarreta o que Foucault chamou de rarefação dos sujeitos que falam: “[...] ninguém entrará na ordem do discurso se não satisfizer a certas exigências ou se não for, de início, qualificado para fazê-lo" (FOUCAULT, 2014, p.35). O processo de rarefação dos sujeitos que falam, advindo da criação da disciplina História, limitou - e ainda hoje sofremos os resquícios desse controle social - o acesso e o teor das produções históricas àqueles que detinham os meios de adquirirem tais qualificações, geralmente pessoas pertencentes às classes mais abastadas. Ao longo do tempo, as exigências necessárias para a inclusão dos indivíduos na disciplina 
foram sendo atualizadas e transformadas, face às novas inquietações e contingências do presente.

Nesse contexto, as últimas décadas assistiram ao falecimento de um projeto escriturário de história fundado no século XIX e ao fortalecimento de um movimento de combate a essa rarefação, por meio da ampliação do direito à voz dentro da disciplina da história, conquistado por grupos historicamente excluídos da ordem do discurso. Esse movimento ficou conhecido como Nova História Cultural, aliado à Nova História Política ${ }^{12}$.

Ainda hoje a tendência historicista influencia o olhar para o passado de professores, alunos e da sociedade em geral, resumindo o senso comum pelo qual entende-se a História. Formulada durante o século XIX, simultaneamente à criação da disciplina, e tendo como seu principal expoente o prussiano Leopold von Ranke, essa corrente pressupunha a possibilidade de reconstrução de determinado acontecimento histórico único por meio de uma narrativa objetiva e imparcial.

Ranke afirmava que o historiador deveria narrar a história a partir de um ponto de vista neutro. Com isso, enxergava a história como um modo de dar sentido aos fatos, mostrando o que de verdadeiramente havia ocorrido, contando com a veracidade das fontes. Seu método consistia em reunir e classificar documentos; fazer uma crítica interna deles; encadear os fatos obtidos pelos documentos; preencher as lacunas deixadas pelas fontes com o seu espírito crítico e organizá-los numa construção lógica.

O trabalho do historiador, então, seria averiguar a autenticidade de suas fontes e montar uma narrativa teleológica coerente e coesa, que minimizasse os perigos do acaso e do improvável e omitisse qualquer juízo de valor, sendo capaz de transportar o leitor para a, então, verdadeira expressão do acontecimento em questão.

Segundo este projeto escriturário, portanto, uma relação de continuidade entre evento e narrativa estava pressuposta, e o texto apresentava-se como uma superfície lisa que refletia a realidade dos eventos passados trazidos à sua forma textual pelo trabalho de pesquisa documental (GUIMARÃES In: GONTIJO, 2007, p. 26).

Não era estimulado qualquer tipo de reflexão suscitada pelo profissional, já que isso era visto como deturpação da objetividade das fontes, resquícios preservados de um tempo inacessível.

\footnotetext{
${ }^{12}$ Ambos os movimentos serão abordados ao final deste subitem.
} 
A História fala e fala por si mesma. O bom historiador se apaga diante dela, deixa-a falar, simplesmente. A História é épica, tem em si mesma seu começo e seu fim, seu telos próprio. A narrativa histórica é a própria História e, portanto, a expressão da verdade (e da realidade) (MONTEIRO, 2007, p. 97).

O poder bélico e os atores políticos, bem como suas ações individuais, ganharam destaque como motores das transformações e avanços da história. Os historiadores desta corrente acreditavam que o Estado era o elemento central para a análise histórica, visto que compunha o elo institucional entre o particular e o público, consistindo verdadeiro núcleo de ações transformadoras. A erudição historiográfica, então, se apoiava nele e estava à serviço do poder real, situada em um momento no qual os Estados nacionais estavam sendo consolidados.

Assim, a história era lida de forma cronológica e linear, em direção a uma ideia cada vez mais forte de progresso, como foi teorizado pelo historiador Reinhart Koselleck como Geschichte. Segundo este autor, ainda o século XVIII assistiu à transformação do velho tópos da história como exemplo instrutivo - Historie nessa nova concepção linear na qual a ação e o seu conhecimento se confundiam ${ }^{13}$.

$\mathrm{Na}$ segunda década do século XX, no entanto, surgiu um movimento historiográfico de contestação ao ordenamento teórico e metodológico da disciplina, dentro de um contexto mundial que já sentia os impactos de uma sociedade de massas e de uma crise que questionava a ideia de progresso da humanidade em direção à acumulação de bens. A Escola dos Annales nasceu em 1929 com a fundação da revista Annales d'histoire économique et sociale, por Lucien Febvre e Marc Bloch, e é reconhecida como representante de um dos movimentos mais significativos de transformações e inovações da produção historiográfica.

A emergência de novas ciências sociais no campo dos debates intelectuais, tais como a sociologia, antropologia, psicologia, economia, etc., acentuou o processo de trocas e interdisciplinaridade entre as mesmas. À luz dessas discussões, os historiadores identificados com a corrente da Escola dos Annales introduziram novos campos de investigação histórica, a partir do reconhecimento da multiplicidade de fontes possíveis de interpretação e análise. Isso permitiu que as histórias sociais, culturais e econômicas pudessem disputar com a até então dominante história política. O movimento questionou o evolucionismo e a ideia de

\footnotetext{
${ }^{13}$ Ver Koselleck, Reinhart. Futuro passado: contribuição à semântica dos tempos históricos. Rio de Janeiro: Contraponto: Ed. PUC-Rio, 2006, p. 48.
} 
progresso e recusou qualquer tipo de dogma, o que garantiu sua plasticidade, mobilidade e integração com um campo de pesquisa mais amplo.

Os historiadores identificados como integrantes dos Annales não tinham um eixo teórico claro, tendo certa pluralidade de abordagens e linhas teóricas, mas possuíam características comuns: posicionamento contra o discurso histórico factual historicista; rompimento com o método positivista atrelado às ideias de racionalidade, progresso e ordem; necessidade de formular questões para orientar e direcionar a pesquisa documental e tendência para a análise de fatos coletivos e mentais, em detrimento dos fatos únicos e individuais valorizados pelos historicistas.

O trabalho do historiador, nesse caso, era pensar a história a partir da problematização dos documentos, orientados por alguma inquietação relevante para a melhor compreensão e aprimoramento das dinâmicas sociais do tempo presente. Sua competência girava em torno de saber localizar os problemas e realizar o interrogatório das fontes de forma adequada na busca das respostas para suas perguntas.

Negava-se assim a ilusão de ser capaz de remontar um passado intangível e aceitava-se a subjetividade inerente do profissional, bem como a aproximação entre passado e presente em relação à elaboração do discurso histórico. “A inovação mais abrangente da historiografia dos Annales é a elevação da dimensão cultural a domínio mais relevante da história, mesmo à condição de seu referencial explicativo/compreensivo mais global"' (SILVEIRA In: CORDEIRO 2010, p. 47).

A Escola dos Annales foi historicamente dividida em três gerações, que não podem ser datadas de maneira taxativa, acompanhando os debates dentro da área $\mathrm{e}$ as mudanças culturais, econômicas, tecnológicas, políticas e sociais mundiais. De forma resumida, a primeira geração ambicionava realizar uma história social global, herança essa reformulada do projeto totalizante do século XIX. A história global seria um estudo metonímico, no qual se analisaria as partes de um todo, buscando correlação verdadeira entre uma série de instâncias da sociedade.

A segunda geração, por sua vez, tentou colocar em prática esse projeto de construção de sentidos harmônica e global entre as instâncias sociais, teorizando sobre as diferentes durações do tempo e suas aplicações práticas em relação a compreensão das fontes e a escrita do discurso histórico. A geo-história braudeliana 
e a história quantitativa dos historiadores demógrafos e economistas são exemplos disso.

A terceira geração concluiu, por fim, que esse projeto da história do todo seria impossível; ela reconheceu, por meio da crítica direcionada ao discurso histórico construído durante a segunda geração, que acabou subjugando o sujeito perante uma estrutura totalizante, a existência de inconsistências em cada temporalidade histórica, sendo sua total apreensão inalcançável. Admitiu-se, finalmente, o desejo do conhecimento pleno de uma realidade outra como impossível. No entanto, essa geração sofreu muitas críticas justamente por realizar uma excessiva fragmentação dos eventos, abandonando o estudo das conjunturas e a articulação dos acontecimentos com a estrutura simbólica social.

A partir da década de 80 do século XX, a aproximação da história com a antropologia colocou em evidência problemas como a generalização dos processos sociais e uma questão metodológica: a centralidade da escrita na produção do conhecimento histórico. As populações indígenas e algumas populações africanas, por exemplo, que historicamente utilizavam a memória oral ou imagética como principal forma de cultura histórica, pugnaram então pelo seu direito a voz, contestando uma concepção de história majoritariamente ligada a escrita.

A entrada desses e de outros grupos historicamente excluídos do processo historiográfico realizou uma nova ampliação do rol de fontes e metodologias até então utilizadas pelos profissionais da área, abrindo novos campos de investigação e, também, novas possibilidades de objeto de estudo eficazes em valores explicativos e significativos.

A Nova História Cultural é demarcada pela diferenciação em relação às outras áreas da história e também em relação ao próprio campo da cultura. Ela tem seu principal foco no processo de resgate do acontecimento e sua consequente vinculação e influência mútua com a estrutura simbólica, criando assim uma interpretação da conjuntura em forma de narrativa. Dessa forma, associa ambas as esferas de análise sem subjugar nem o sujeito e a ação nem a estrutura no qual está inserido. Ela também recebe o nome de História Social da Cultura, evidenciando o caráter central da sociedade enquanto conceito coletivo, plural, instável e polifônico, em consonância com o conceito de cultura explicitado no primeiro subitem deste capítulo. 
A ideia é "a de que os fatores político-culturais são instituintes da realidade social e não simples 'derivações"” (GOMES In: GOUVÊA, 2005, p. 25). Da mesma maneira, os pensamentos e a agência dos diversos grupos sociais são relevantes para o trabalho do historiador, e não apenas o da classe dominante, geralmente detentora dos meios institucionais de divulgação e propagação ideológicos. Nesse processo, estudos representativos sobre grupos identitários tais como mulheres, população LGBT, pessoas com deficiência, indígenas, quilombolas, dentre outros, receberam destaque da historiografia. Esse delicado equilíbrio entre macro e micro é atualmente tanto um dos principais desafios para os historiadores quanto uma das tendências de análise significativa mais promissoras para o tempo presente.

Simultaneamente, também começou a ser repensado o conceito de política, a partir da introdução de novos sujeitos com voz ativa neste campo, proporcionado pela ascensão de movimentos sociais. Além disso, a sofisticação analítica em relação aos poderes discursivos existentes internamente entre dominantes e dominados do tecido social, agora não mais restritas aos regimes e sistemas de governo institucionais, também contribuíram para a reformulação do conceito.

Sobre esse assunto, as considerações sobre os estudos de Foucault feitas no início deste subitem são bastante presentes. As relações de poder permeiam intrinsecamente a dinâmica das relações sociais, ampliando o campo de investigação do que é o político.

De uma forma geral, pode-se dizer que tal conjunto retomava o grande tema da questão social, recusando a predominância de um enfoque sócioeconômico mais estrutural, e passando a privilegiar abordagens que ressaltavam variáveis políticas e culturais, para um melhor entendimento das relações sociais construídas entre dominantes e dominados (GOMES In: GOUVÊA, 2005, p. 23).

A aproximação entre Nova História Cultural e Nova História Política representa parte do processo de desconstrução do fenômeno de rarefação do sujeito dentro do discurso histórico, possibilitando iluminar situações e jogos de poder até então naturalizadas e contribuindo para a formação e o fortalecimento de novas identidades sociais.

A historiadora Ângela de Castro Gomes utiliza o conceito "cultura política" para definir esse conjunto, visto que ele "reúne de forma paradigmática os dois termos da equação em que as relações de dominação vêm sendo revisitadas pela 
historiografia brasileira, o que instiga a uma reflexão sobre sua articulação com os estudos históricos" (GOMES In: GOUVÊA, 2005, p. 23).

Dentro das diversidades de culturas políticas no interior de qualquer sociedade, é importante ressaltar que esse conceito de média ou longa duração expressa um sistema de representações múltiplo, tenso e complexo, que permite a diferentes grupos construírem uma compreensão da realidade social e de suas identidades culturais em um determinado período de tempo, reestruturando e ressignificando as ações dos atores sociais de acordo com uma certa visão de mundo. Assim, conforme a relação entre cultura, sociedade e história que está sendo construída neste capítulo,

O conceito de cultura política incorpora sempre uma leitura do passado - histórico ou mítico, ou ambos -, que conota positiva ou negativamente períodos, personagens, eventos, textos referenciais e, principalmente, um enredo - uma narrativa - do próprio passado. Nesse sentido, estudar uma cultura política, ou melhor, trabalhar com sua formação e divulgação - quando, quem, através de que instrumentos -, é entender como uma certa interpretação do passado (e do futuro) é produzida e consolidada, integrando-se ao imaginário ou à memória coletiva de grupos sociais, inclusive os nacionais (GOMES, In: GOUVÊA, 2005, p. 32 e 33).

O capítulo 3 deste trabalho monográfico irá abordar de forma mais aprofundada essa discussão acerca da relação entre história e memória. Antes disso, no entanto, é necessário ressaltar que essa análise sobre a construção do discurso histórico e suas esferas relacionais de poder sociais deve ser transposta para o âmbito escolar, pois entendo a escola como detentora de cultura política e peculiaridades pedagógicas próprias, que não podem ser ignoradas ou generalizadas pelo olhar historiográfico.

\subsection{O Discurso Histórico Escolar}

A instituição escolar é parte fundamental da sociedade e tem papel preponderante no processo de difusão e ressignificação dos saberes institucionalizados. Da mesma forma que visa contribuir para a inserção dos jovens nesta sociedade, também sofre influência da mesma a todo momento. Assim, como a esfera macrossocial, o ambiente escolar é caracterizado por múltiplas vozes e relações de poder, com a presença constante de diferenças, apresentadas e desenvolvidas não só nas trajetórias e bagagens de vida particulares de cada aluno, 
mas também no quadro de professores(as), funcionários(as) e pela comunidade ao redor $^{14}$.

Não cabe, assim, uma interpretação da escola e da sala de aula como lugares neutros ou imparciais, visto que as disputas de poder ocorrem desde a formulação curricular formal até nas relações cotidianas de ensino-aprendizagem, no qual entra em cena o currículo oculto ${ }^{15}$. Sobre isso, Foucault afirma:

A educação, embora seja, de direito, o instrumento graças ao qual todo indivíduo, em uma sociedade como a nossa, pode ter acesso a qualquer tipo de discurso, é bem sabido que segue, em sua distribuição, no que permite e no que impede, as linhas que são marcadas pela distância, pelas oposições e lutas sociais (FOUCAULT, 2014, p. 41).

A História, nesse contexto, é uma disciplina rica e necessária para refletir a respeito da nossa experiência como humanos e cidadãos, já que lida com vivências das mais plurais, subjetividades, concepções de mundo, grupos culturais, espaços e representações sociais que permitem uma ampliação da percepção de mundo, servindo como parâmetro legitimador para a realidade social presente.

A História escolar é uma enorme e polivalente lição de coisas sociais, morais e intelectuais. Ela pode insuflar nos alunos tanto conformidade como o distanciamento, a continuidade e a reavaliação de práticas, valores e de representações. Terreno complexo para a definição de aprendizagens específicas (MONTEIRO, In: GOUVÊA, 2005, p. 444).

A construção de sentidos é facilitada, ainda, pela presença cotidiana dos assuntos estudados, em uma relação passado-presente na vida dos alunos. Como afirma a historiadora Maria Lima, "O desconhecimento do passado significa sofrêlo com passividade, pois alcançar a dimensão da própria história pressupõe a tomada de consciência do que se é e do que se foi, rompendo com a perspectiva da alienação" (LIMA, 2014, pp. 56).

Assim, mais do que o domínio dos saberes históricos institucionais, ao professor de história cabe a tarefa de compreensão da historicidade da vida social, realizando a partir de então um processo de transposição didática que já começou na formulação do currículo formal, mas que tem sua continuação no trabalho docente.

\footnotetext{
${ }^{14}$ Ver MONTEIRO, Ana Maria. "Os saberes que ensinam: o saber escolar" In: de História: entre saberes e práticas. Rio de Janeiro: ed. Mauad X, 2007 p. 82.

${ }^{15}$ Saberes e valores ensinados de forma implícita, a partir de comportamentos, rituais e prática sociais. Não entram no currículo formal. Professores
} 
Esse conceito utilizado por Ana Maria Monteiro é apropriado de Chevallard e diz respeito à adaptação necessária do conhecimento científico em conhecimento didático escolar: "Ao trabalho que transforma um objeto de saber a ensinar em um objeto de ensino denominamos transposição didática" (CHEVALLARD, 1991:45, In: MONTEIRO, 2007, p. 85). A transposição didática feita pelo professor parte do princípio que o processo de ensino-aprendizagem envolve uma preocupação relacional entre quem aprende e quem ensina.

Esse processo é diferente da aquisição teórica produzida nos espaços acadêmicos, nos quais o foco da inteligibilidade é a epistemologia do conhecimento científico. O conhecimento escolar deve levar em consideração uma série de habilidades e competências responsáveis pela verdadeira assimilação e incorporação do conhecimento ao aparelho psico-cognitivo do aluno, de forma que só assim pode se transformar em ferramenta subjetiva de leitura, organização e reestruturação da realidade.

O papel do professor, em consonância com a teoria socioconstrutivista do psicólogo russo Lev Vygotsky ${ }^{16}$, deve ser, portanto, o de mediador entre o conhecimento e o aluno, permitindo que este construa sua interpretação da realidade de forma interativa com os colegas e com o próprio conhecimento. Nessa interpretação o professor é visto como uma ponte, cuja tarefa é estimular o pensamento crítico por meio de constantes atividades que levem os alunos a questionarem e se apropriarem do conhecimento ensinado de acordo com seu contexto pessoal e social.

Corroboro com a interpretação de Ilmar Rohloff de Mattos ${ }^{17}$ de que o discurso histórico escolar construído por cada professor possui expressivo cunho autoral, pois o processo de preparação das aulas e seleção de conteúdos é feito a partir de escolhas individuais de dimensões axiológicas (valorativas) perante uma ampla gama de conhecimentos científicos acadêmicos, portais de conhecimentos secundários, experiências pessoais, situações cotidianas em foco na mídia, peças de teatro, novelas, documentários, filmes, exposições, etc. No entanto, o embasamento

\footnotetext{
${ }^{16}$ Ver MORETTO, Vasco Pedro. Construtivismo: a produção do conhecimento em aula. 3. ed. Rio de Janeiro: DP\&A, 2003, p. 95 e 96.

${ }^{17}$ Ver MATTOS, Ilmar Rohloff de. "Mas não somente assim!" Leitores, autores, aulas como texto e o ensino-aprendizagem de História. Tempo, Niterói, v. 11, n 21, p.5-16, junho 2006.
} 
do conhecimento científico, em geral, ainda provém majoritariamente dos trabalhos historiográficos.

Assim, o discurso histórico escolar, como prática social de construção de significado, deve manter constante diálogo com a academia, objetivando a atualização desse saber histórico na direção de sempre acompanhar as transformações sociais de forma contestadora. Para isso, é necessário que esse discurso se adapte e se integre às múltiplas realidades características do ambiente escolar, pugnando por seu caráter democratizante, a fim de que seu conteúdo possa construir significados válidos perante o corpo discente e a sociedade.

Desde a década de 70 do século XX, principalmente a partir dos estudos identificados com a Nova História Cultural e a Nova História Política, as pautas de diversos grupos sociais historicamente excluídos vêm conseguindo entrar no espaço da historiografia como conteúdos relevantes para a análise histórica e sua exposição didática. Essa adesão foi fruto das demandas sociais latentes de maior representação desses mesmos grupos, articulados em movimentos organizados, como o Movimento Feminista e o Movimento Negro.

A ampliação dos temas de estudo proporcionado pela Nova História Cultural e pela Nova História Política suscitou um diálogo mais eficiente entre as pautas presentes e a construção do conhecimento histórico escolar, incentivando o interesse e facilitando a construção de significado pelos alunos pertencentes aos grupos sociais excluídos. Esses estudantes não se viam representados na história contada e, assim, não conseguiam estabelecer laços culturais com os processos históricos.

Isso consistiu em mais um avanço em direção a uma educação cada vez mais democrática, em consonância com nosso aparato legal institucional:

A educação destina-se a múltiplos sujeitos e tem como objetivo a troca de saberes, a socialização e o confronto do conhecimento, segundo diferentes abordagens, exercidas por pessoas de diferentes condições físicas, sensoriais, intelectuais e emocionais, classes sociais, crenças, etnias, gêneros, origens, contextos socioculturais, e da cidade, do campo e de aldeias (BRASIL, 2013, p. 27).

O poder de contestação das estruturas encontrou, assim, seu principal polo na cultura, entendida como conjunto de práticas sociais. Assim, o movimento de formulação do conhecimento histórico pode ser também ascendente, ou seja, 
proveniente do cotidiano cultural da sociedade, e não só descendente, relacionado aos conhecimentos construídos dentro do cientificismo acadêmico.

Isso significa que mudanças culturais também afetam os currículos escolares, partes da esfera institucional do Estado e frutos de um campo conflituoso de disputas de projetos educacionais e concepções de sociedade. "Daí entenderem que toda política curricular é uma política cultural" (Diretrizes Curriculares Nacionais para a Educação Básica, 2013, p. 26). Nesse contexto, vale ressaltar que: “Todo sistema de educação é uma maneira política de manter ou de modificar a apropriação dos discursos, com os saberes e os poderes que eles trazem consigo" (FOUCAULT, 2014, p. 41).

$\mathrm{Na}$ prática, tem-se contestado o antigo projeto educacional nacional e uniformizante, no qual a escola deveria formar o cidadão brasileiro em sua perspectiva única e alinhada aos valores da classe dominante:

A tradição da história oficial tradicional, oriunda do século XIX, com uma acentuada vertente nacionalista e integracionista, que ocultava ou negava as contradições sociais na busca de uma imagem pacifista e legitimadora de formas de dominação seculares, foi rompida (MONTEIRO In: GOUVÊA, 2005, p. 444).

Conquista desses movimentos de reivindicação foi a implantação da lei 10.639, de 2003, que tornou obrigatório o ensino de História da África e de história e cultura afro-brasileira em todas as escolas do país. Essa inclusão caracteriza mais uma alteração e recriação de conteúdos curriculares frente às demandas sociais culturais e representa uma importante vitória rumo a um ensino menos racista e unilateral.

Dessa forma, se partirmos da compreensão do passado como algo múltiplo e constantemente reavaliado e reconstruído, inclusive na expressão dos produtos culturais que o evocam, a aula de história também deve ser pensada em sua multiplicidade, em suas inúmeras possibilidades, num diálogo permanente entre o tempo vivido no presente e as diversas formas de apreensão e interpretação do passado, por alunos e professores (MAGALHÃES, 2014, p 8).

A Nova História Cultural também proporcionou o resgate da narrativa na forma como a história é escrita e contada. Os historicistas do século XIX se empenharam num movimento de cientifização da história, distinguindo-a ao máximo da literatura. Para isso, ocultaram o narrador do discurso, visando reforçar uma ideia de narratividade objetiva e cronológica. Os fatos eram organizados num modelo explicativo, com início, meio e fim. 
Quando se fortaleceu a corrente historiográfica da Escola dos Annales, essa narratividade passou a ser negada por ser associada a uma escrita factual e superficial, que não levava em consideração as subjetividades de construção do texto narrativo. Porém, o movimento historiográfico da Nova História Cultural evidenciou que a negação da narrativa na verdade corroborava com um projeto global estruturante, que não elevava o acontecimento ao status de objeto de análise. Era necessário então o resgate da narrativa, porém não da mesma forma com que esta era construída no século XIX.

Agora, a narrativa deve ser formulada a partir de questionamentos e problemas. Ela não deve ser apenas uma descrição de acontecimentos, mas deve suscitar, a partir do relato, questionamentos sobre a dinâmica das sociedades e ampliar o rol de interpretações possíveis. "A narrativa histórica é ponto inicial, e a partir dela existe a possibilidade da compreensão dos acontecimentos por meio das ações dos sujeitos" (BITTENCOURT, 2008, p. 144). Ela deve, por fim, ser capaz de gerar reflexão.

O resgate da narrativa teve um grande impacto na construção do discurso histórico escolar contemporâneo como ferramenta de criação e aproximação de sentidos entre o conhecimento científico e o corpo discente. Isso porque corrobora para um processo de didatização do discurso histórico acadêmico, permitindo a construção de imagens mentais mais concretas e completas, no lugar de esquemas abstratos mais dificilmente compreendidos pelo sistema psico-cognitivo do cérebro humano.

O discurso histórico escolar atual deve possibilitar ao aluno sua autonomia na construção de sentidos no mundo por meio de representações historicamente formuladas e reformuladas. Se o objetivo da educação é a formação plena do cidadão, é necessário que este seja capaz de escolher criticamente entre as diversas representações pelas quais esse mesmo mundo é construído e que saiba se posicionar historicamente na sociedade.

Afinal... aprender História é aprender sobre nós mesmos. É aprender sobre a diversidade das experiências humanas através dos tempos e nos diferentes lugares. É aprender que o homem é o conjunto de suas práticas como sujeito, protagonista, e ao mesmo tempo sujeito à sua circunstância, no fazer da cultura. Aprender que o diferente nos homens de qualquer tempo e lugar nos é familiar porque a humanidade é uma, mas a cultura é plural (MONTEIRO In: GOUVÊA, 2005, p. 448). 
Assim, o discurso histórico escolar é fundamental para a edificação de uma memória coletiva, que orienta posicionamentos e comportamentos, assim como para a construção das identidades dos discentes. Construído por meio de representações que corroboram ou confrontam visões identitárias presentes na estrutura simbólica de nossa cultura, ele atua como prática social edificadora de significado. Portanto, a forma com a qual os professores elaboram seu discurso histórico escolar é de extrema relevância no cotidiano da aula de história. Essas questões serão abordadas nos capítulos 2 e 3, mas por ora é interessante ressaltar que a onda cultural política que vivemos atualmente traz uma pluralidade de questionamentos e perspectivas. Isso se torna um desafio e um estímulo para o docente de História pois:

Hoje confronta-nos o desafio de contemplar a multiplicidade do mundo e sua indeterminação para auxiliar nossos alunos e construir sua memória e suas identidades a partir de uma História que considere as rupturas, conflitos, crises públicas e privadas, em suas infinitas diferenças (MONTEIRO, 2007, p. 110). 


\section{Capítulo 2: Construção Social das Identidades e Diferenças}

\subsection{Identidade e Diferença: Conceitos Relacionais}

No capítulo anterior busquei demonstrar que o discurso, enquanto prática social simbólica e atitudinal, é mecanismo de construção e reconstrução de significados no mundo. Ancorado na linguagem, é também por meio dele que as identidades e as diferenças ganham sentido e são formuladas e reformuladas. Assim, as identidades, ou seja, as projeções do "eu" no mundo, são construídas por meio da dupla face social/simbólica.

Isso significa afirmar que a identidade e a diferença são conceitos relacionais e culturais, construídos no bojo das diversas sociedades ao longo do tempo, e não podem, portanto, ser falsamente interpretados como naturais ou transcendentais. Se considerarmos as identidades e diferenças como elaborações dentro de um discurso de cunho linguístico, que por sua vez guarda um aspecto cultural, tal afirmação parece meio óbvia. Porém é sempre importante frisá-la, pois no cotidiano tendemos a reduzir as identidades e diferenças como fatos dados da vida, constâncias normativas tomadas como prontas, acabadas.

Essa redução fica clara quando pensamos em classificações identitárias básicas, tais como: homem/mulher e branco/negro. Pensamos nelas em termos visuais e concretos, com suas distinções ancoradas em sistemas biológicos solidificados pela sociedade ocidental como sendo opostos a qualquer sistema cultural. Esquecemos que na verdade essas identidades primárias são construções discursivas e carregam uma quantidade enorme de elementos subentendidos, demarcando a atuação dos grupos sociais, bem como a forma como eles se veem e são vistos; além de exporem os limites do considerável e/ou aceitável para cada grupo.

Esquecemos, por fim, mergulhados na estrutura discursiva de poderes históricos, que os sistemas de significação são instáveis. É característica intrínseca do signo ser adaptável, mutável. Dessa forma, se os discursos são marcados pela sua constante plasticidade, seus produtos, dentre eles a identidade e a diferença, os quais dependem dessa mesma estrutura, também o são. Como afirma Tomaz Tadeu 
da Silva, especialista em teoria educacional crítica, "somos dependentes, neste caso, de uma estrutura que balança" (SILVA, 2000, p. 80).

A identidade é sustentada neste trabalho como um conceito relacional. Ela depende para existir de um contraponto, a diferença, pois só há lógica em demarcar uma característica se existem outras das quais se quer distanciar. É a partir do reconhecimento do "outro" que estabelecemos quem somos, tanto a nível individual quanto a nível coletivo; a partir dessa relação constrói-se a regra e a não regra, alimentando um sistema de divisões e hierarquias sociais.

A identidade, assim, só faz sentido dentro de uma cadeia de diferenciação linguística/social sustentada por um sistema de exclusão ${ }^{18}$. Isso porque a nossa percepção do "eu" está calcada na nossa percepção do "não eu”; reforçar o ser significa negar um infinito de outras classificações. Quando dizemos, por exemplo, que somos brasileiros, estamos negando implicitamente todas as outras nacionalidades e suas características culturais em prol de elementos historicamente construídos como constitutivos da brasilidade.

\subsection{Como as Identidades e Diferenças São Construídas?}

A construção da identidade e da diferença é feita a partir de representações, que atuam "simbolicamente para classificar o mundo e nossas relações no seu interior" (Hall, 1997a apud Silva, 2000, p. 8). É por meio delas que os significados são criados e os seres humanos são posicionados como sujeitos, bem como seus limites e possibilidades são estabelecidos; é a partir das representações sociais que as pessoas assimilam quais são os comportamentos adequados para cada situação social. Logo, identidade e diferença dependem das representações sociais e só existem ancoradas nelas.

Numa perspectiva pós-estruturalista, a representação incorpora todas as características instáveis e ambíguas do discurso, como qualquer sistema de significação. Assim, ela também está sujeita às relações de poder sociais e seu caráter arbitrário. Todos nós, enquanto brasileiros, temos, por exemplo, uma imagem mental clássica, persistente, do ser uma boa mãe, que é por sua vez

\footnotetext{
${ }^{18}$ Argumento de Judith Butler, parafraseado por Stuart Hall. Para mais detalhes ver Silva, 2000, p .129 .
} 
diferente do ser um bom pai, apesar de ambos possuírem mesmo nível de relação parental para com o filho/a.

Enquanto a imagem tradicional da boa mãe implica características dóceis, relativas ao lar e afetivas, a imagem do bom pai assimila a imposição da ordem e da disciplina, bem como a inserção na esfera pública do trabalho. Qualquer fuga a essa norma coletiva substabelecida inconscientemente ocasiona uma série de sofrimentos advindos de julgamentos internos e externos sobre determinado ideal representativo não estar sendo cumprido de forma satisfatória. Percebemos, nesse exemplo, que as diferentes representações são ocasionadas pelo fator do gênero (feminino/mãe e masculino/pai) e suas consequentes posições-de-sujeitos.

Isso é bastante danoso para o grande grupo de famílias plurais e não nucleares existentes em quantidade cada vez maior, no Brasil, pois indica que a discrepância dos modelos representativos em relação à realidade sociocultural não está diminuindo em direção a abarcar cada vez mais as multiplicidades emergentes. Podemos citar como exemplo as famílias chefiadas por mães ou avós ou compostas por pais de mesmo gênero.

As posições-de-sujeito, criadas pelas representações, são como nos colocamos e nos comportamos face aos papeis esperados dentro dos sistemas de classificação representativos sociais. Isso não significa que não haja margem para contestação e resistência, como podemos observar nas tensões existentes em relação aos modelos tradicionais de mãe e pai, principalmente no que tange ao âmbito doméstico e na crescente urgência de uma divisão mais igualitária das tarefas.

No entanto, culturalmente, existe um consenso mínimo entre os membros de uma sociedade para classificar as coisas e as pessoas, bem como a repetição desse padrão comportamental estabelecido, a fim de manter uma certa coesão social. É a partir de tal repetição de representações que as diferentes identidades se tornam inteligíveis.

Embora tenhamos a falsa impressão subjetiva de possuir uma identidade única, atuamos e nos expressamos de formas diversas em múltiplos momentos e campos sociais, tais como na família, no trabalho, na escola, nos grupos de amizade, etc. "Nós participamos dessas instituições ou 'campos sociais', exercendo graus variados de escolha e autonomia, mas cada um deles tem um contexto material e, na verdade, um espaço e um lugar, bem como um conjunto de recursos simbólicos" (Woodward In: Silva, 2000, p. 31). Isso significa que a nossa percepção de si como 
indivíduos é integral, mas nos âmbitos socioculturais de atuação cotidiana entram em cena componentes hierárquicos de dominação e transgressão, que limitam nosso poder de atuação e autonomia ou modificam nossa posição-de-sujeito - o que é esperado de cada pessoa frente a determinado papel social.

No ambiente doméstico mais íntimo, por exemplo, nossa posição-de-sujeito dentro de uma classificação de classe ou raça não se destaca de forma relevante visto que geralmente existe uma relação simétrica e similar entre as pessoas; no entanto, é neste mesmo ambiente que as posições-de-sujeito de gênero podem ganhar protagonismo. Em resumo: "os discursos e os sistemas de representação constroem os lugares a partir dos quais os indivíduos podem se posicionar e a partir dos quais podem falar" (Silva, 2000, p. 17).

No entanto, para que as identidades possam ser posições assumíveis pelo indivíduo, é necessário não só ser colocado numa posição classificatória determinada pelos outros, mas também o próprio sujeito precisa se ver em tal posição e investir nessa representação identitária. É preciso, assim, da presença de um elemento psíquico subjetivo, sem o qual nenhum sistema institucional disciplinar teria o efeito controlador desejado, pois "quaisquer que sejam os conjuntos de significados construídos pelos discursos, eles só podem ser eficazes se eles nos recrutam como sujeitos" (Silva, 2000, p. 55).

Identidade e subjetividade muitas vezes são interpretados como conceitos substituíveis; eles podem ser, de fato, correlatos, visto que nutrem relações de dependência. No entanto, enquanto a identidade é tida como um posicionamento social, influenciada por contingências discursivas culturais e materiais, a subjetividade é constituída de características de reconhecimento psíquico conscientes e inconscientes, ou seja, é a compreensão que cada um de nós fazemos do nosso eu. A subjetividade abarca nossos pensamentos e emoções e é fundamental para o processo de elaboração de uma imagem particular do que somos, pois os significados construídos socialmente devem ser apropriados por elas, num processo de assimilação, sujeição e investimento pessoal.

A definição de quem nós somos é um processo muito importante para a formação da nossa psique, sendo elementar para a expressão satisfatória dos nossos desejos. Ela não é, portanto, cem por cento consciente e depende da internalização de visões sociais exteriores de reconhecimento, que nomeiam e posicionam esse sujeito no rol dos processos simbólicos e sociais. Stuart Hall denomina essa 
internalização como uma costura entre o psíquico e o discursivo, ou seja, uma articulação contingencial entre o sujeito e o social ${ }^{19}$.

Por lidar com características psíquicas e inconscientes, as identidades não constituem decisões racionais e ordenadas, constituindo-se "pontos de apego temporário às posições-de-sujeito que as práticas discursivas constroem para nós" (Hall In Silva, 2000, p. 112). Podem existir discrepâncias entre o nível coletivo e o nível pessoal, além de negociações constantes entre identidades conflitantes. Nesse contexto, um mesmo indivíduo pode assumir diferentes posições de sujeito e se identificar com elas, porém estas podem se mostrar em conflito na prática social. Por exemplo, as identidades de mulher trabalhadora e boa mãe muitas vezes se chocam dentro da estrutura patriarcal, na qual a primeira deve ser dedicada e proativa e a segunda deve ser zelosa e protetora.

No entanto, é sempre válido frisar que o processo de identificação não é nunca completamente determinado, visto que ele não é singular e limitado ao período da primeira infância e adolescência. Durante toda a vida, as diferentes identificações podem ser afirmadas, e podem ser também rechaçadas em posterior momento, num movimento constante de estranhamento, desequilíbrio e consequente alteração de percepção face às contingências materiais e as formações subjetivas. Assim, "embora tenha suas condições determinadas de existência, o que inclui os recursos materiais e simbólicos exigidos para sustentá-la, a identificação é, ao fim e ao cabo, alojada na contingência" (Hall In: Silva, 2000, p. 106).

As identidades e diferenças atuam no mundo social por meio de símbolos e manifestações culturais. O corpo, então, é uma esfera importante de projeção de significados, pois exteriorizamos quem somos por meio de comportamentos, roupas, expressões linguísticas, uso de determinados objetos e acessórios, comida, hábitos, etc. Também é por meio dele que sofremos as represálias caso apresentemos alguma fuga aos padrões identitários estabelecidos, concretizados em discriminações muitas vezes baseadas em condições fenotípicas, como a cor da pele, o gênero ou a presença de alguma deficiência.

A identificação por meio do reconhecimento de práticas ou modos de ser comuns, criando bases de solidariedade, passa pelo domínio do corpo, embora ele não seja soberano nesse processo. O corpo atua, nesse sentido, como parte do

\footnotetext{
${ }^{19}$ Ver Hall, In Silva, 2000, p. 112.
} 
processo de estabelecimento de fronteiras que define quem nós somos e, por consequência, nos distingue dos outros. Portanto, "é precisamente sob essa forma que o corpo tem funcionado como o significante da condensação das subjetividades no indivíduo [...]" (Hall In: Silva, 2000, p. 121). Nessa relação confusa e indeterminada entre subjetividade, identidade e corpo, devemos, então, reconhecer e valorizar não só nosso corpo como também os dos outros, pois eles são a única forma pela qual podemos experimentar o mundo.

Se como mostrado ao longo deste capítulo a diferença é, portanto, a operação básica de organização da psique individual, da língua e da cultura, a única constância desses sistemas mutáveis criadores de identidades, por que temos tanta dificuldade de lidar com ela? Para responder a essa questão é preciso discutir sobre a atual crise de identidade pós-moderna.

\subsection{Crise de Identidade: Identidades Fragmentadas}

Stuart Hall, no seu livro intitulado A identidade cultural na pós-modernidade, elabora um pensamento lúcido, o qual reafirmo, de que o final do século XX e o início do século XXI protagonizaram um momento de deslocamento das estruturas simbólicas de sustentação da sociedade moderna, "abalando os quadros de referência que davam aos indivíduos uma ancoragem estável no mundo social" (Hall, 2011, p. 7).

Essa fissura no status quo, que se supunha ser estável, fixo e coerente, envolveu diversas áreas da sociedade e possibilitou o aparecimento de múltiplos questionamentos e incertezas alavancadas por novas experiências individuais e coletivas. Dentro desse processo, a percepção e elaboração das identidades também sofreram uma transformação, concretizada em um movimento de fragmentação cultural, configurando o que Stuart Hall chamou de uma "crise de identidade".

A crise de identidade acontece quando colocamos em dúvida quem nós somos: "esta perda de um 'sentido de si' estável é chamada, algumas vezes, de deslocamento ou descentração do sujeito" (Hall, 2011, p. 9). Ela é vivida individualmente algumas ou várias vezes ao longo de nossas vidas, como resultado da articulação de nossa subjetividade com nossas experiências no mundo social.

No entanto, o argumento deste item é que essa crise de identidade também está sendo vivida coletivamente, em um nível social amplo. A partir da segunda 
metade do século XX, o mundo vivenciou uma série de transformações econômicas, políticas e culturais que refletiram o fim do período que conhecemos como modernidade, iniciando a atual fase da modernidade tardia.

As transformações sociais dessa época contribuíram para solapar a concepção Iluminista de sujeito, em contestação já desde o início do século XX. O conceito de sujeito, em seu sentido de percepção de si e como construção discursiva e cultural, está exposto às contingências históricas das sociedades, tendo seu significado sofrido alterações ao longo do tempo. Nessa concepção Iluminista patriarcal de vivenciar a individualidade, o homem era entendido como um ser racional, centrado, indivisível, hermético e singular, cuja identidade era mantida essencialmente a mesma durante toda a sua vida, apenas desenvolvendo princípios já presentes desde o nascimento.

Esse modelo conceitual representou uma grande mudança em relação ao papel dominante da tradição e das hierarquias sociais vigentes, visto que, ao dotar o homem de potencial criativo, colocou em cheque velhas estruturas medievais e religiosas. Importantes teorias econômicas e filosóficas liberais foram criadas ao longo dos séculos XVII e XVIII, evidenciando a concepção individualista e soberana de sujeito e corroborando para os contornos da organização social moderna.

Sabemos, com base nas reflexões feitas até aqui, que essa forma de "narrativização do eu" (Hall In: Silva, 2000, p. 109) coerente e objetiva é fruto de construções sociais inventadas, assim como todas as demais. No entanto, a consciência de sua invenção não a torna menos eficaz em seus aspectos discursivo, material e político. Isso sugere a compreensão de que o ser humano, ao longo do tempo, nunca foi tão unificado quanto se sugeriu, mas que a crença de que tenha sido provocou vivências e impactos sociais que não devem ser menosprezados.

No século XVIII, porém, o conceito de sujeito foi deslocado de uma visão individualista para uma visão sociológica, tendo seu ápice no século XIX. Essa última perspectiva foi caracterizada pelo englobamento do ser humano em associações e burocratizações administrativas dos nascentes e complexos Estadosnações. O surgimento das novas ciências sociais colaborou para um processo de 
cientifização e biologização do humano que, apesar de ainda indivíduo singular, possuía sua essência sujeitada à dinâmica de suas relações sociais ${ }^{20}$.

Assim, as identidades dos indivíduos eram moldadas a partir da relação de um "eu", não mais autônomo ou autossuficiente, com o sistema social, em uma estável troca interativa na qual o sujeito interiorizava concepções externas e ao mesmo tempo exteriorizava sua essência. A frase popular "diga com quem andas e te direi quem és" poderia ser adequadamente aplicada a esse modelo de teorização sociológica que via o meio como mediador de valores e símbolos estruturais.

Percebe-se que, apesar de ter acontecido um processo de flexibilização da concepção singular e autossuficiente do sujeito Iluminista, o sujeito sociológico ainda é caracterizado a partir de uma identidade coesa e bem definida, só que agora determinada pelo seu meio social e o conjunto de suas relações. É justamente essa coesão e essa certeza de definição que começaram a ser contestadas na modernidade $\operatorname{tardia}^{21}$.

A partir da segunda metade do século $\mathrm{XX}$, dois elementos passaram a ser fortemente questionados à luz das teorias construtivistas promovidas pelos movimentos sociais, tais como o movimento feminista e o movimento negro; são eles: a presença de uma essência identitária inata e o protagonismo da razão e do consciente, a partir da descoberta do inconsciente promovida por Freud ${ }^{22}$.

É nessa época que começa a ser construída a visão do sujeito pós-moderno fragmentado, que vivencia seu ápice no contexto da virada do século e, arrisco dizer, ainda hoje mantém-se como categoria social adequadamente aplicável. Nela, as identidades são vistas como um processo sempre em andamento. A possibilidade de completude ou determinação é impossível e ilusória, posto que estamos sempre expostos a possibilidades de novas identificações em um mundo sociocultural cada vez mais dinâmico e transformativo.

Os estudos teórico-linguísticos assumem papel central nas discussões pósmodernas. Dentre eles, destaco aqui o impacto da teoria feminista como elemento descentralizador, pois ele foi capaz de expandir a reflexão sobre áreas de vivência até então consideradas sob a ótica da biologia e do particular, trazendo-as para a esfera do debate político das relações de poder, tais como a família, a divisão sexual

\footnotetext{
${ }^{20}$ Ver Hall, 2011, p. 30-31.

${ }^{21}$ Ver Hall, 2011, p. 34-46.

${ }^{22}$ Ver Hall, 2011, p. 36.
} 
do trabalho, a sexualidade, a maternidade/paternidade, etc. Isso ajudou no processo de enfraquecimento do componente biológico e no fortalecimento do elemento histórico de interpretação social. Destaco aqui passagem de Tomaz Silva, que traduz muito bem este ponto.

As chamadas interpretações biológicas são, antes de serem biológicas, interpretações, isto é, elas não são mais do que a imposição de uma matriz de significação sobre uma matéria que, sem elas, não tem qualquer significado. Todos os essencialismos são, assim, culturais. Todos os essencialismos nascem do movimento de fixação que caracteriza o processo de produção da identidade e da diferença (Silva, 2000, p. 86).

O movimento feminista mostrou, afinal, que a construção das identidades também é sujeitada ao discurso de gênero, questionando os padrões de dominação. Com isso, evidenciou-se o caráter cultural e subjetivo dos atos políticos, antes obscurecidos pela luta de classes de cunho materialista. Nesse sentido, o movimento feminista ajudou a mitigar a supremacia da classe como identidade mestra, já que elucidou, e a partir disso essa constatação não poderia mais ser ignorada, a opressão de gênero como transversal a ela. Da mesma forma, transferiu as disputas políticas do campo ideológico para o campo identitário, abrindo espaço para o surgimento de diferentes identidades culturais.

O que era tradicionalmente fixo e coerente, na modernidade assumiu caráter transitório e instável. "As sociedades modernas são, portanto, por definição, sociedades de mudança constante, rápida e permanente" (Hall, 2011, p. 15). As identidades singulares norteadoras, relacionadas por exemplo às nações ou aos partidos políticos, se transformaram em identidades múltiplas, contraditórias e deslocadas. Esse é o caráter da modernidade, levado até seu extremo nas sociedades da modernidade tardia, as quais

[...] são caracterizadas pela "diferença"; elas são atravessadas por diferentes divisões e antagonismos sociais que produzem uma variedade de diferentes "posições de sujeito" - isto é, identidades - para os indivíduos. Se tais sociedades não se desintegram totalmente não é porque elas são unificadas, mas porque seus diferentes elementos e identidades pode, sob certas circunstâncias, ser conjuntamente articulados. Mas essa articulação é sempre parcial: a estrutura da identidade permanece aberta (Hall, 2011, p. 18).

Conseguimos entender, dessa forma, por que vivenciamos uma crise de identidade. A incerteza e a pluralidade de centros identitários não combinam com os modelos institucionais fixos, unitários e englobantes, tais como nação, linhagem, família partido, igreja, etc., que tentam sedimentar padrões de comportamento. 
"Novas formas de sociabilidade vão se desenvolver, acompanhando os paradigmas emergentes" (Velho, 1999, p. 98). Elas causam incômodo, balançam as estruturas sociais. Nesse contexto, talvez o maior desses modelos institucionais abalados seja, ainda hoje, a identidade nacional.

\subsection{Identidade Nacional e Globalização}

A identidade nacional é formada de representações comumente assimiladas por indivíduos que se identificam como pertencentes a uma mesma cultura, identificada como uma nação, sendo esta, portanto, nada mais do que uma comunidade simbólica imaginada ${ }^{23}$, construída por práticas sociais e relações de poder, cujo objetivo é alimentar sentimentos de lealdade, coesão e identificação. Abordarei no capítulo 3 desta monografia alguns elementos essenciais para a construção desses sentimentos e o papel chave da História como legitimadora social de uma memória coletiva e um projeto de futuro.

Por ora, o argumento que aqui interessa é o de que, para atingir esse fim, a afirmação dessa identidade nacional precisou obscurecer diferenças que ameaçassem a formação de um conjunto homogêneo, tais como diferenças relacionadas a classe, raça, gênero e sexualidade. Esse processo historicamente não foi feito de forma pacífica, e sim através da supressão violenta da diferença, tanto simbolicamente - repressão a movimentos culturais, criminalização de manifestações identitárias postas como imorais - quanto fisicamente - perseguição, agressão e morte de indivíduos que manifestassem publicamente comportamentos externos à norma ${ }^{24}$.

Afirmo, nesse contexto, que as identidades nacionais nunca foram homogêneas ou unificadas, mas precisou-se criar uma ilusão macrossocial de que assim foram. Apesar de no inconsciente coletivo ainda existir a assimilação e o reconhecimento de uma cultura nacional, as nações modernas são todas constituídas

\footnotetext{
${ }^{23}$ Para saber mais sobre a formação das identidades nacionais, ver "Comunidades imaginadas", de Benedict Anderson.

${ }^{24}$ No Decreto ${ }^{\circ}$ 847, de 11 de outubro de 1890, conhecido como Código Penal dos Estados Unidos do Brazil, a capoeira era inserida como forma de "vadiagem" e seus praticantes poderiam ser punidos com dois a seis meses de prisão. Para saber mais a respeito consultar ROESLER, Átila da Rold. Sobre a vadiagem e o preconceito nosso de cada dia. Justificando, 9 ago. 2016, site. Disponível em <http://www.justificando.com/2016/08/09/sobre-a-vadiagem-e-o-preconceito-nosso-de-cada-dia/>. Acesso em 25 nov. 2018.
} 
de múltiplas culturas, constituindo-se em híbridos culturais (Hall, 2011, p. 63); visão que está cada vez mais aparente como resultado do processo de globalização mundial.

O fenômeno da globalização potencializado no pós Guerra Fria, que cessou uma extrema polarização mundial, vem contundentemente descentrando essas identidades nacionais e reconstruindo as comunidades imaginadas. Ele representa a suavização dos limites fronteiriços impostos entre as diversas comunidades, tanto territorialmente quanto culturalmente, tornando o mundo mais interconectado. "À medida em que as culturas nacionais tornam-se mais expostas a influências externas, é difícil conservar as identidades culturais intactas ou impedir que elas se tornem enfraquecidas através do bombardeamento e da infiltração cultural" (Hall, 2011, p. 74).

Esse bombardeamento cultural, através do contato com diferentes realidades, gera sentimentos de estranhamento e desequilíbrio nos indivíduos. Dessa forma, observamos cada vez mais identidades desvinculadas de um espaço cultural determinado e a criação de tensões, mas também possibilidades de articulação entre o local e o global. Podemos utilizar o exemplo do cabelo cacheado afro ou crespo, que vem, ao redor da cultura ocidental, da qual o Brasil faz parte, sendo usado transnacionalmente como símbolo de empoderamento negro. Localmente, este mesmo símbolo reconhecido além das fronteiras do Brasil pode carregar particularidades que abarquem elementos culturais brasileiros.

No entanto, não acredito que isso indique a dissolução das identidades nacionais, como acreditam alguns estudiosos. Corroboro com Hall quando afirmo que elas estão sendo na verdade deslocadas do lugar de centro ordenador das formações identitárias individuais e sociais, em prol de um movimento de maior articulação com novas identificações locais e regionais.

Além da criação dessas novas identidades mais fluidas, a globalização também acaba gerando, em paralelo, um movimento de reforço ou fixação das identidades antigas. "O processo de produção da identidade oscila entre dois movimentos: de um lado, estão aqueles processos quem tendem a fixar e a estabilizar a identidade; de outro, os processos quem tendem a subvertê-la e a desestabilizá-la" (Silva, 2000, p. 84). Esse movimento conservador/fixo pode ser lido como uma reação defensiva e de resistência às mudanças globais, geralmente - mas não exclusivamente - impulsionados por grupos identitários dominantes, que 
lutam pela manutenção de sua hegemonia cultural. Esses grupos encabeçam apelos para as chamadas "raízes" culturais e identitárias, que fazem referência, por sua vez, a normalizações construídas historicamente.

As sólidas localizações identitárias que sustentavam a organização social sofreram abalos irreparáveis. A globalização gerou um efeito pluralizante em relação às identidades, ampliando o rol de possibilidades de identificação e posições-de-sujeito referentes à classe, raça, gênero, sexualidade, nacionalidade, etc. Observamos, então, a reorganização da luta política em torno da afirmação/repressão de identidades singulares cada vez mais fluidas e móveis, em choque com os antigos conceitos relacionados ao unitarismo e à fixidez, assunto esse para o próximo item.

\subsection{Entre Fixação e Fluidez: As Disputas Relacionais de Poder}

A cultura, enquanto prática social, estabelece categorias básicas e padrões positivos de ordenamento identitários, que são normalizados e elevados a categoria de regra, consequentemente excluindo ou marginalizando o que é considerado como sendo o "outro". Ela age como mediadora entre as experiências humanas e seu controle disciplinar, visto que

Separar, purificar, demarcar e punir transgressões têm como sua principal função impor algum tipo de sistema a uma experiência inerentemente desordenada. É apenas exagerando a diferença entre o que está dentro e o que está fora, acima e abaixo, homem e mulher, a favor e contra, que se cria a aparência de alguma ordem (Douglas, 1966, p. 4 apud Silva, 2000, p. 46).

O processo de normalização é uma forma sutil e eficaz de hierarquização social, já que ela consiste em eleger arbitrariamente como parâmetro uma determinada identidade em detrimento das demais. Essa reunião de elementos positivos em uma só identidade cria por consequência um sentimento de falta nas marginalizadas, que é traduzido pelo apagamento da própria noção de identidade naquela considerada padrão e de constante reforço da diferença como algo negativo nas outras muitas.

$\mathrm{Na}$ sociedade brasileira podemos usar como exemplo do quadro identitário acima a característica da masculinidade. Na maioria dos veículos midiáticos temos a representação padrão do masculino como salvaguarda de uma série de valores 
considerados positivos, tais como força, virilidade, inteligência, sagacidade, aventura, inovação, rapidez, racionalidade, etc. De tanta repetição cotidiana, criase um imaginário, uma fórmula representativa na qual a identidade masculina não é sequer vista como tal; ela não é uma, mas $a$ identidade, construída de tal forma que é tida como uma essência completa em si mesma.

Por outro lado, a identidade feminina é a todo momento generificada. Como afirmou Simone de Beauvoir, a mulher vive sempre marcada pelo estereótipo da negatividade, da falta, do "outro", no qual o referencial é o homem² ${ }^{25}$. Ela tem sempre a incumbência de provar para a sociedade que possui os valores positivos resguardados aos homens, enquanto a estes não lhes é colocada nenhuma dúvida de sua integridade como indivíduo.

Podemos perceber que o elemento normalizador cria posições-de-sujeito em relação a uma norma que permanece invisível; qualquer diferença é tida como um desvio, um acidente, uma marca negativa. Isso também pode ser observado nos casos da supremacia branca, heterossexual e sem deficiência e, a nível mais amplo, no caso da supremacia estadunidense e europeia dentro da esfera ocidental, quiçá mundial, com o recorrente uso da palavra "exótico" para referir-se às demais culturas.

Procurarei evidenciar, no capítulo seguinte, como essa normalização está presente no discurso histórico escolar e como ela afeta a construção das identidades dos estudantes, mas por hora vale dizer que qualquer norma identitária é falsa porque "aquilo que é deixado de fora é sempre parte da definição e da constituição do 'dentro"' (Silva, 2000, p. 84).

Nesse contexto, é possível afirmar que "a ordem social é mantida por meio de oposições binárias" (Silva, 2000, p. 46), que expressam relações de poder desiguais, entre os detentores do poder de representar e de definir e aqueles que não o possuem. Nessa polarização das categorias binárias, um dos elementos sempre será mais valorizado, sendo essa a base para as divisões e hierarquias sociais e materiais, das quais nos são mais evidentes as divisões de gênero, raça e sexualidade, todas elas em relação única com as classes sociais.

\footnotetext{
${ }^{25}$ Ver RIBEIRO, Djamila. O que é lugar de fala?. Belo Horizonte: Letramento: Justificando, 2017, p. $35-38$
} 
Portanto, "a identidade e a diferença estão, pois, em estreita conexão com relações de poder. $O$ poder de definir a identidade e de marcar a diferença não pode ser separado das relações mais amplas de poder. A identidade e a diferença não são, nunca, inocentes" (Silva, 2000, p. 81). Isso significa que as identidades não estão relacionadas de forma harmônica na sociedade; pelo contrário, elas são a todo momento impostas, disputadas e reformuladas, em um embate de desconstrução e reafirmação de antigos padrões.

Assim, para subverter a lógica da desigualdade, é necessário um movimento direcionado ao fim das dicotomias e oposições binárias em prol de um imaginário coletivo que gire em torno da celebração da existência, de forma íntegra, de múltiplas identidades, sem o estabelecimento de um ponto de referência fixo; tal referência, aliás, deve ser unicamente a própria diferença, único elemento constante no cenário histórico/cultural.

É preciso substituir, então, o fixo pelo contingente e reconhecer posições e lugares de fala nas fronteiras das classificações identitárias, pois a opressão hegemônica não se dá de maneira universal; ela apresenta matizes, sobreposições e esferas diferenciadas de ação. Como afirma Tomaz Silva, "a fixação é uma tendência e, ao mesmo tempo, uma impossibilidade" (Silva, 2000, p. 84).

É interessante, a essa altura, estabelecer o conceito de performatividade como elemento chave para a discussão, pois apenas descrever a forma arbitrária e hierárquica com as quais as identidades e diferenças são construídas somente colabora para seu processo de fixação social. Para contornar esse problema, o conceito de performatividade, primeiramente desenvolvido por J. A. Austin, mas ampliado pela teórica Judith Butler, salienta o caráter transformador do discurso ${ }^{26}$.

Austin afirma que o discurso possui proposições que, ao serem constantemente ditas e repetidas, reforçam seu poder de concretude na realidade presente. Exemplos desse caráter performativo da linguagem estão em diversas orações popularmente conhecidas, tais como: "Eu vos declaro marido e mulher" e "declaro aberta a sessão".

Butler, no entanto, amplia a aplicabilidade do conceito de performatividade da área linguística para a área social e o insere na produção das identidades. Ela afirma que a repetição de adjetivações, que teoricamente teriam apenas objetivo

\footnotetext{
${ }^{26}$ Para mais sobre o conceito de performatividade, ver Silva, 2000, p. 92-96.
} 
descritivo, sobre determinadas características identitárias de grupos sociais, pode acabar acarretando o reconhecimento e a consequente identificação de indivíduos com tais características, tanto positiva quanto negativamente, alavancando práticas sociais deturpadas.

O conceito de performatividade desloca a ênfase na identidade como descrição, como aquilo que é - uma ênfase que é, de certa forma, mantida pelo conceito de representação - para a ideia de "tornar-se", para uma concepção da identidade como movimento e transformação (Silva, 2000, p. 92).

Podemos voltar ao exemplo do cabelo cacheado do tipo crespo, constituinte da identidade negra. Ao longo do tempo criou-se, com eficácia produtiva, através da repetição, a associação entre cabelo cacheado, considerado "ruim" ou feio, e cabelo liso, considerado "bom" ou bonito. Assim, quando nos utilizamos de adjetivos pejorativos que associam o cabelo cacheado ao cabelo "ruim" o que está acontecendo não é uma mera descrição, mas a perpetuação discursiva da negatividade associada à identidade negra e, de forma mais ampla, ao continente africano em sua multiplicidade étnica.

Essa costura realizada entre o psíquico e o discursivo, ou seja, entre o reconhecimento de um tipo de cabelo, no espelho, e sua identificação subjetiva a adjetivos negativos como feio ou ruim, pode provocar danos psicológicos e identitários, inclusive resultando em processos de transformação física, mesmo que essa transformação não seja conscientemente compreendida como uma negação forçada do efeito discursivo, tanto para si, quanto para os outros. Nesse caso, o cabelo é só um exemplo para transformações que podem assumir caráter bem mais grave e permanente, como cirurgias plásticas ou mutilações.

Da mesma forma, quando um professor se refere a determinado aluno como “pouco inteligente" ou "preguiçoso" ele está ajudando a moldar posições-de-sujeito e, consequentemente, noções de identidade do próprio estudante e dos seus colegas ao redor, que reconhecem subjetivamente aquela posição a partir do olhar do professor. "É de sua repetição e, sobretudo, da possibilidade de sua repetição, que vem a força que um ato linguístico desse tipo tem no processo de produção da identidade" (Silva, 2000, p. 94). Essa possibilidade de repetição acontece quando determinada adjetivação já está tão recorrente que é normalizada, assimilada como verdade pelos indivíduos, que a utilizam em outras circunstâncias sem questionamento. 
O potencial performativo do discurso adquire papel transformador quando, ao invés de contribuir para reforçar hierarquias sociais existentes, colabora no processo de interrupção das identidades hegemônicas por meio da cessão de sua repetição. É possível extrair novas representações e construir novas identidades ao criticar esses modelos historicamente configurados. É o caso dos diversos movimentos sociais afirmativos que buscam igualdade de condições e representações justas, através do resgate de símbolos identitários, do constrangimento da norma e da ênfase na celebração da diferença.

A diferença pode ser construída negativamente - por meio da exclusão ou da marginalização daquelas pessoas que são definidas como "outros" ou forasteiros. Por outro lado, ela pode ser celebrada como fonte de diversidade, heterogeneidade e hibridismo, sendo vista como enriquecedora [...] (Silva, 2000, p. 50).

Em relação ao exemplo citado sobre o cabelo cacheado, o movimento negro das últimas décadas tem realizado uma releitura performativa dessa representação negativa. A partir disso, houve, por parte dos integrantes desse movimento, a cessão da vinculação entre cabelo cacheado e cabelo "ruim", bem como a valorização da beleza do cabelo afro por meio de campanhas relacionando-o a status poderosos e positivos. Atualmente, observamos uma crescente mobilização social para a exibição orgulhosa dos cachos, assimilando-os como símbolo positivo metonímico da identidade negra.

Se a imposição normativa era o cabelo liso e o cabelo cacheado era considerado o "outro" marginalizado, agora essa imposição encontra-se enfraquecida e o cenário capitalista globalizado da moda abre espaço para a convivência de ambos os tipos de cabelo. Isso não significa que o processo de opressão discursiva tenha tido fim, nem que as pessoas negras de cabelo cacheado ainda não sofram com a supremacia da identidade branca, mas indica o potencial transformador que a performatividade do discurso associada a um movimento social possui para a alteração da realidade material e simbólica.

O ponto, que será mais debatido no próximo capítulo, é que ao contestar a identidade como caráter fixo e imutável, e valorizar as diferenças por meio de um discurso performativo positivo como outras identidades inteiras - no qual o ponto de referência é a própria diferença ao invés de outra identidade normatizada -, estamos na verdade afetando também a estrutura hierárquica de poder em sua forma mais básica de produção de desigualdade: a representação binária. 
O combate ao binarismo através da valorização das fronteiras e do pensamento crítico pode ser visto como prática social ativa de construção de uma sociedade mais justa e democrática, na qual os indivíduos possam se reconhecer como sujeitos plenos, e assim atuar no mundo como tais. Nesse contexto, a história como disciplina escolar tem um papel fundamental, como veremos no próximo capítulo. 


\section{Capítulo 3: História, Memória e Multiculturalismo Performativo}

\subsection{O passado como elemento chave na formação da cultura política nacional}

Vimos no capítulo anterior como que, em ordem de se criar e se sustentar uma comunidade imaginada denominada como nação, foi preciso historicamente solapar as múltiplas diferenças identitárias sociais tais como gênero, raça, sexualidade, deficiência, etc., dentro de uma cultura nacional maior.

$\mathrm{Na}$ prática, essas questões nunca deixaram de existir, porém foram relegadas a um papel secundário dentro da construção do Estado Brasileiro e da identidade nacional, sustentada e autenticada por uma mesma história compartilhada. "Uma das formas pelas quais as identidades estabelecem suas reivindicações é por meio do apelo a antecedentes históricos" (Woodward In: Silva, 2000, p. 11). Assim, a partir do momento em que esses antecedentes históricos são construídos não apenas por instituições, mas também por representações as quais podemos nos identificar, eles constroem identidades.

O estudo da História, portanto, foi usado desde o século XIX como ferramenta política, moral e cívica de legitimação dos poderes institucionais, estabelecendo normalizações e tradições nacionais essencialistas, ou seja, caracterizadas como verdades imutáveis. Para isso, a educação formal foi seu principal esteio ${ }^{27}$.

Embora tenham existido consideráveis mudanças na construção do discurso histórico escolar desde o século XIX, que acompanharam as transformações nacionais e mundiais concomitantemente à revisão de correntes historiográficas já discutidas no capítulo 1 desta monografia -, podemos achar determinadas semelhanças, que chamarei de tradicionais, contrastantes com a atual preocupação institucional e social de democratizar o ambiente escolar, à luz das transformações sociais localizadas na pós-modernidade.

O discurso histórico escolar até a ditadura militar produziu uma narrativa eminentemente calcada nas noções de pátria, tradição, família e nação. Com certa

\footnotetext{
${ }^{27}$ Ver Fonseca, 2017, p. 41-75.
} 
alteração nos atores históricos escolhidos, a presença de "brasileiros célebres" 28 (FONSECA, 2017, p. 60) foi constantemente incentivada como motivo de representação de valores heroicos que valiam a pena ser exaltados. Esses atores eram majoritariamente integrantes de uma ou mais identidades dominantes na hierarquia social, guardando características consideradas virtuosas, associadas à masculinidade, à heterossexualidade e à branquitude. Com base na teoria de Von Martius sobre a mistura das três raças - branca, negra e amarela ou indígena -, o ensino de história consagrou uma ideia ilusória de harmonia e democracia racial, que na verdade exaltava a colonização portuguesa e a cultura branca europeia, colocando as demais raças como subordinadas de uma direção claramente elitizada ${ }^{29}$.

Os negros escravizados, dessa forma, eram - e infelizmente por vezes ainda são - representados no discurso histórico escolar apenas como mercadoria ou mãode-obra, sempre como vítimas submissas aos seus senhores brancos, presos aos grilhões de sofrimento da estrutura da escravidão. As formas de resistência à escravidão, quando abordadas, também geralmente ainda giram em torno dos quilombos e das manifestações violentas de luta. As múltiplas formas de resistência cultural ou ainda as complexidades da sociedade escravista são ignoradas ou tratadas de forma menos relevante.

Nesse sentido destaco o jongo como manifestação não violenta de importância histórica, geralmente esquecido ou ignorado. O jongo é uma dança que possui forma de sociabilidade própria, pois para as canções, chamadas de ponto, e a comunicação de maneira geral funcionarem, é preciso que seus participantes dominem um campo linguístico/simbólico específico, formado por metáforas. Ele foi elaborado durante o século XIX por negros escravizados em diversos lugares ao longo das fazendas de café da região sudeste do país como um padrão cultural de resistência construído nas experiências da escravidão.

As canções elaboradas eram construídas de forma astuta, por “ $[(. .$.$) gente que$ aprendeu] a arte do subterfúgio e da ironia como um meio-termo entre a submissão e a revolta" (B. A. Botkin apud Slenes, 2007, p. 112), e tinham várias funções, tais como aliviar e criar laços de solidariedade nas tarefas de trabalho em grupo, festejar, alertar sobre a chegada do senhor ou do feitor, etc. Na prática social, o jongo teve

\footnotetext{
${ }^{29}$ Ver Fonseca, 2017, p. 50.
} 
um papel muito relevante na construção de uma comunidade escrava que reconhecia experiências e identidades comuns, muitas vezes remontando um léxico cultural e histórico provindo de áreas semelhantes do continente africano.

No entanto, essa parte da história não é levada em consideração na maior parte das vezes durante o processo de elaboração do discurso histórico escolar nas salas de aula brasileiras. Nenhuma menção a "palavra - ou imagem - sobre outros aspectos do cotidiano, como as festas, batuques, procissões, conversações ocorridas nas ruas" (Fonseca, 2017, p. 100). Essa visão reducionista e maniqueísta, que é mantida e atualizada com a categoria do malandro e do vagabundo no estudo sobre o Brasil República, fomenta uma cultura política na qual a identidade negra é representada apenas ligada ao trabalho pesado e à violência, gerando dessa forma um inconsciente coletivo que associa essas pessoas às condições materiais e ao trabalho braçal, afastando-as dos trabalhos intelectuais, mais valorizados na sociedade brasileira. "A circulação do conhecimento histórico está, portanto, atrelada às maneiras de narrar e comunicar a narrativa" (Fonseca, 2017, p. 108).

Ora, se a única forma pela qual o estudante negro se vê repetidamente representado na narrativa histórica construída nas salas de aula da Educação Básica é desta forma deturpada, ou seja, se sua única conexão com esse passado legitimador do presente é através da violência, do trabalho braçal ou da vagabundagem, e se essa visão não é contestada, logo a construção do seu "eu" sua visão sobre si, suas possibilidades e seus limites - será estabelecida por um processo de subjetivação individual e inconsciente dessa realidade como norma, de acordo com o caráter performativo desse discurso.

Às estudantes meninas, podemos ainda acrescentar a marcação sexual atrelada ao gênero, que só agrava o quadro montado até aqui ao salientar o corpo feminino como um instrumento de agradabilidade ao homem, considerado nessa perspectiva como único referencial, detentor de autonomia. $\mathrm{O}$ corpo exageradamente sexualizado da mulher é, então, supervalorizado como meio principal pelo qual ela pode construir suas interações com o mundo, obscurecendo o rol de possibilidades criativas de caráter intelectual pelo qual elas podem também experienciar a realidade. O estereótipo de gênero se forma, então, quando as posições-de-sujeito femininas são formuladas em função de seu corpo, e não em função de sua atuação integral como indivíduos na práxis social, como no caso dos homens. Assim é que, na prática, as discentes são desestimuladas a escolherem 
carreiras que envolvam atividades intelectuais, como raciocínio lógico e cálculo, em prol de carreiras que envolvam mais o uso do corpo, tais como teatro e dança, sendo problemáticas não estas últimas ocupações, mas sua atribuição normativa impositiva.

A máxima, nesse contexto, era gerar um sentimento de conformação e ajuste em relação à realidade social, e não de contestação ou reflexão crítica:

“Este seria o caminho para a formação do 'cidadão', do homem ideal, que melhor serviria aos interesses do Estado (...). Nessa concepção, a ordem social, livre de conflitos, seria fator de progresso e as desigualdades seriam legitimadas como fatos universais e naturais" (Fonseca, 2017, p. 62).

É claro que não estou querendo, com isso, estabelecer uma relação direta e inescapável. Já refleti sobre a importância do caráter difuso e subjetivo da construção das identidades e das diferenças, nem de longe calcadas em uma única esfera social tal como a escola. O conjunto dos pedaços fragmentados de identificação perpassa todos os grupos sociais, de produção cultural, nos quais um indivíduo está envolvido; todos eles ajudam no seu processo de pensar a si próprio em relação ao diferente. No entanto, neste trabalho monográfico, destaco a relevância do espaço escolar como parte significativa dessa produção, por considerá-lo local cujo objetivo é a reflexão e o debate, característica muitas vezes ausentes em outros espaços de sociabilidade.

Essas representações históricas, tendo esse contexto social plural em mente e apesar de suas nuances, foram repetidas e reproduzidas não só por meio das instituições governamentais, tendo a escola como seu principal veículo, mas também apropriadas por meio da literatura, da mídia e da cultura popular, como no caso dos temas carnavalescos das escolas de samba ou nas tramas das telenovelas, estes três últimos influenciados também por outros aspectos relacionais de poder, tais como o gosto da audiência ou a pressão econômica dos patrocinadores.

Todos esses locais de expressão ajudam a construir "uma série de histórias, imagens, panoramas, cenários, eventos históricos, símbolos e rituais nacionais que simbolizam ou representam as experiências partilhadas, as perdas, os triunfos e os desastres que dão sentido à nação" (Hall, 2011, p. 52). Dessa forma, eles acabam criando uma cultura política - cujo conceito foi discutido no capítulo 1 -, que se apoia numa memória coletiva. 
Essa memória comum nos orienta enquanto indivíduos dentro de uma coletividade, ou seja, constrói um sentimento de pertencimento, garantindo significado a nossa vida, ao ligar por laços de continuidade o indivíduo a uma esfera maior e perene - a nação; e, ao mesmo tempo, projetar um ideal de futuro comum. Isso foi resumido por Hall na seguinte passagem: “devemos ter em mente esses três conceitos, ressonantes daquilo que constitui uma cultura nacional como uma 'comunidade imaginada': as memórias do passado; o desejo por viver em conjunto, a perpetuação da herança" (Hall, 2011, p. 58).

\subsection{Memória Passada e Projeto Futuro}

Se, na pós-modernidade atual, a identidade nacional se fragmentou em vista da ascensão à superfície social consciente das identidades pessoais, isso significa que também a memória coletiva e o projeto de futuro não puderam mais se sustentar como unitários. Isso porque "a consciência do projeto depende, fundamentalmente, da memória que fornece os indicadores básicos de um passado que produziu as circunstâncias do presente, sem a consciência das quais seria impossível ter ou elaborar projetos" (Velho, 1999, p. 101). As referências passadas, em constante processo de individualização, desconstrução e reconstrução presentes, projetam assim novas e diferentes metas de futuro, mais plurais e condizentes com a "crise do tempo histórico linear-progressivo e às formas estruturais de conceber a própria explicação histórica" (Diehl, 2002, p. 123), advindas junto a era da globalização e tecnologização intensas.

Esse processo foi analisado pelo historiador Reinhart Koselleck, que teorizou sobre a tensão e a assimetria modernas entre as categorias de temporalidade histórica intituladas pelo autor como "espaço de experiência" e "horizonte de expectativa" ${ }^{30}$. O "espaço de experiência" pode ser resumido aqui, já que não é intenção deste trabalho se aprofundar nesta discussão, como as memórias individual e coletiva; são aqueles acontecimentos vividos, contextualizados e incorporados qualitativamente à memória, ao consciente. Já o "horizonte de expectativa" pode

\footnotetext{
30 Para saber mais, ver KOSELLECK, Reinhart. "Espaço de experiência" e "horizonte de expectativa": duas categorias históricas. In: Futuro passado: contribuição à semântica dos tempos históricos. Rio de Janeiro: Contraponto: Ed. PUC-Rio, 2006, p. 305-327.
} 
ser sintetizado como o futuro que ainda não chegou, mas pelo qual lançam-se esperanças ou medos. "Em outras palavras: todas as histórias foram construídas pelas experiências vividas e pelas expectativas das pessoas que atuam ou que sofrem" (Koselleck, 2006, p. 306).

Recuperar essas histórias por meio de uma narrativa que destaque os elementos identitários subjetivos e sociais dos indivíduos participantes, como pessoas inteiras, se mostra adequado para combater os fenômenos da rarefação do sujeito e da performatividade negativa, sendo uma adaptação necessária aos tempos presentes.

"Tempos, pois, de ambivalência, de múltiplos sentidos em movimento, de decisões na incerteza, de subversões, de hegemonias contingenciais, de um presente com novas propostas de equacionamento das tensões entre 'campos de experiência' e 'horizontes de expectativas'" (Moreira; Candau, 2008, p. 215).

Todos nós, enquanto indivíduos, elaboramos projetos pessoais de futuro para nossas vidas, que ordenam e significam as nossas múltiplas e contraditórias experiências, intensificadas pela pós-modernidade. Em época escolar, principalmente durante o Ensino Médio, é importante, por exemplo, a preocupação com o projeto de carreira, seja por meio de um curso superior, um curso técnicoprofissionalizante ou então um emprego de carteira assinada.

No entanto, não me parece equivocado afirmar que é a noção de identidade que articula esse projeto de futuro em sua relação com os fragmentos de memória pessoal e coletiva. Como afirma o antropólogo Gilberto Velho: “O sentido de identidade depende em grande parte da organização desses pedaços, fragmentos de fatos e episódios separados. O passado, assim é descontínuo" (Velho, 1999, p. $103)$.

Dessa forma, o projeto de futuro profissional dos estudantes acaba sendo inserido e ao mesmo tempo limitado pelo seu campo de possibilidades, ou horizonte de expectativas, o qual, por sua vez, é dependente de sua visão de si no meio social, não constituindo processo inteiramente consciente. Afirmo que esse processo é, novamente, histórico e que, portanto, o discurso histórico escolar assume relevância que não deve ser ignorada. 
Podemos, para ilustração, relembrar novamente o caso do jovem aluno negro, em constante contato com representações que associam a identidade negra a valores sociais negativos ou submissos. Conforme os anos escolares vão passando e " $a$ medida que o indivíduo se destaca e é cada vez mais sujeito" (Velho, 1999, p.98), sua construção de identidade pode, tendo em vista o não questionamento desse cenário representativo, ser constituída de forma que se veja, interiorize e se projete numa posição-de-sujeito inferior, gerando uma baixa autoestima a nível social que se reflete na realidade presente.

No estado do Rio de Janeiro, por exemplo, em pesquisa realizada pelo Ministério do Trabalho e Emprego (RAIS 2016), a desigualdade salarial entre brancos e negros era de 69,3\%. Além disso, o percentual de pessoas negras ocupando profissões menos qualificadas e com menor remuneração é maior que o de pessoas brancas. Essa desigualdade pode ser observada não só no Rio de Janeiro, como em todo o país. Se colocarmos o fator gênero na equação, no mesmo ano os homens tinham um percentual de rendimento habitual mensal médio 76,5\% maior, considerando todo o Brasil. ${ }^{31}$

Vale salientar que a visão de si é sempre pautada na visão do outro sobre si e, portanto, longe desta pesquisa querer incutir qualquer espécie de culpa nos grupos vulneráveis aqui elencados. O que venho tentando apresentar nesta pesquisa é a inserção da discussão identitária ao cenário social e histórico. "A identidade, por conseguinte, depende dessa relação do projeto do seu sujeito com a sociedade, em um permanente processo interativo" (Velho, 1999, p. 104). Portanto, as condições psicológicas de identificação e subjetivação têm o poder de reforçar e perpetuar, ao lado das condições materiais de nível amplo, o cenário de desigualdade social brasileiro gritante, a partir do tolhimento dos campos de possibilidades dos alunos negros, em comparação com o dos alunos brancos.

\footnotetext{
${ }^{31}$ Dados retirados do G1, em matéria publicada por Helton Simões Gomes, em 14/05/2018, intitulada "Brancos são maioria em empregos de elite e negros ocupam vagas sem qualificação". Disponível em <https://g1.globo.com/economia/noticia/brancos-sao-maioria-em-empregos-deelite-e-negros-ocupam-vagas-sem-qualificacao.ghtml> e também de levantamento do IBGE, intitulado "Estatísticas de Gênero: indicadores sociais das mulheres no Brasil". Estudos e Pesquisas: Informação Demográfica e Socioeconômica, n. 38, 2018. Disponível em < https://agenciadenoticias.ibge.gov.br/media/com_mediaibge/arquivos/9d6f4faedalf1fb7532be7a92 40cc233.pdf>. Acesso em 25 jun. 2018.
} 


\subsection{Multiculturalismo Performativo}

A normalização presente nos discursos por meio de representações unilaterais, dentre eles o discurso histórico escolar, é problemática porque ajuda a perpetuar um padrão identitário que é parcial, ilusório e historicamente construído em cima de relações hierárquicas de poder. Ele solidifica tais hierarquias ao nunca colocar as identidades hegemônicas sob a luz da alteridade e a todo momento relembrar o caráter desviante das demais. "Questionar a identidade e a diferença como relações de poder significa problematizar os binarismos em torno dos quais elas se organizam" (Silva, 2000, p. 83); e isso significa, por fim, questionar os sistemas de representação que lhe oferecem suporte.

Assim, acredito que possamos elaborar uma conexão entre os pensamentos dos autores apresentados no consistente à formulação de uma postura prática profissional em relação ao conhecimento histórico escolar, denominado por mim de multiculturalismo performativo. A ideia é que, ampliando os grupos sociais representados no discurso histórico e tratando-os como identidades inteiras referenciadas na própria diferença e não em outra concepção identitária normativa - seja possível a construção de um pensamento reflexivo sobre a realidade. A partir disso, os discentes obteriam os subsídios críticos necessários para a tomada, se assim for desejado, de uma atitude de transformação social em direção a um Brasil menos desigual.

Aqui se encontra o potencial performativo positivo da educação. Não basta apenas afirmar e descrever a existência de diferentes identidades e culturas, pois apenas isso não contesta e não busca alterar a sua classificação binária arbitrária e as relações de poder intrínsecas a ela. São, afinal, essas relações de poder, ao longo das práticas sociais, que reproduzem as desigualdades, tanto materiais, quanto simbólicas. Não é suficiente apoiar-se em "um vago e benevolente apelo à tolerância e ao respeito para com a diversidade e a diferença" (Silva, 2000, p. 73), como denominou Silva, pois nessa perspectiva " a diferença e a identidade tendem a ser naturalizadas, cristalizadas, essencializadas" (Silva, 2000, p. 73).

É necessário, no contraponto, adotar uma posição ativa de combate aos fatos e dados da vida social, enfatizando o caráter artificial dessas relações identitárias, por meio de uma postura cultural, política, crítica e reflexiva. "O que a teoria 
[social] cultural ressalta é que, ao confundir a estabilidade e a fixação da identidade, a hibridização, de alguma forma, também afeta o poder" (Silva, 2000, p. 87). Por fim,

É preciso, também, enfrentar as implicações políticas e epistemológicas dessas denúncias, explicitações, defesas e combates na possibilidade de estabelecimento de relações entre sujeitos e saberes em tempos em que o próprio entendimento sobre esses termos é percebido também como campo de disputa (Moreira; Candau, 2008, p. 213).

Questionar as representações identitárias, feitas a partir do discurso histórico escolar pelo(a) professor(a) de história, então, passa a não ser só possível, mas necessário, a fim de se enfrentar dinamicamente as desigualdades historicamente consolidadas - e objetivamente caminhar em direção a um país melhor para todos, na qualidade de suas diferenças.

“A pedagogia e o currículo deveriam ser capazes de oferecer oportunidades para que as crianças e os/as jovens desenvolvessem capacidades de crítica e questionamento dos sistemas e das formas dominantes de representação da identidade e da diferença" (Silva, 2000, p. 92).

A sala de aula, ainda hoje, ocupa um espaço central de produção e reflexão de diferenças por meio dos discursos. Por mais que faça parte da instituição escolar, um órgão governamental que intrinsecamente busca gerar aquele conjunto de valores nacionais, isso não anula o potencial performativo dos discursos produzidos dentro dela. Foi assim historicamente com as performatividades negativas, e não é diferente, portanto, se a deslocarmos visando seu potencial positivo. Afinal, a diferença é fundamental ao sistema democrático e possui papel pedagógico. Diferença e ordem social não são conceitos violentamente antagônicos; pelo contrário, são inter-relacionais.

A forma de se representar os atores sociais nos diversos acontecimentos históricos, produzidos tanto no ambiente acadêmico quanto no ambiente social cultural faz, portanto, toda a diferença para a apropriação do conhecimento histórico escolar, suas permanências na memória coletiva e na formulação das identidades. 
Para isso, defendo a construção do conhecimento histórico escolar descentrado, aos moldes do sentido que Natalie Davis confere ao termo ${ }^{32}$.

A ideia de Davis, e que aqui transponho para o(a) professor(a), é que ele(a) construa uma narrativa histórica que seja social e geograficamente ampla. Primeiramente, introduzindo múltiplas vozes e oportunidades de fala aos sujeitos participantes de determinado acontecimento histórico, e não só aos sujeitos pertencentes à elite. Isso adiciona ao panorama narrativo todos aqueles indivíduos marginalizados das esferas hegemônicas de poder, tais como as mulheres, os negros, os indígenas, as classes com menor poder de renda etc. Esses grupos sociais devem ser tratados como pessoas com identidades inteiras, ou seja, como indivíduos capazes de estabelecer relações e formular criativamente seus próprios destinos, dentro de seus respectivos "campos de experiências" e "horizontes de expectativas" (Koselleck, 2006).

Nessa perspectiva descentrada, aos escravizados devem ser conferidas oportunidades narrativas protagonistas: abordar o jongo como construção cultural comunitária ao longo da experiência do cárcere, salientando sua permanência no período republicano como manifestação cultural identitária, é um bom exemplo, assim como também mostrar as diferentes perspectivas entre os grupos de escravizados durante o episódio da Revolta do Malês. Da mesma forma, as mulheres podem e devem ser representadas fora do binarismo de gênero, ou seja, não apenas relacionadas ao masculino, geralmente trancafiadas aos papeis sociais figurativos de esposa e mãe, mas com pensamento próprio e participação na esfera cultural e política - ainda que esse pensamento corrobore com o status quo e não assuma caráter revolucionário.

Os historiadores Peter Linebaugh e Marcus Rediker realizaram com excelência esse trabalho de descentração histórica em seu livro A hidra de muitas cabeças: marinheiros, escravos, plebeus e a história oculta do Atlântico revolucionário. Por meio da metáfora da hidra, eles exploram no capítulo intitulado "Os párias das nações da terra" a multiplicidade, o movimento e a conexão dos diversos grupos sociais que manifestavam oposição à dominação hegemônica

\footnotetext{
${ }^{32}$ Para saber mais, ver DAVIS, Natalie Z. Descentering history: local stories and cultural crossings in a global world. History and Theory, 50, may 2011, p. 188-2
} 
colonial, apresentando uma construção narrativa onde prevaleceu o intercâmbio e a hibridização de ideias e práticas sociais.

O capítulo narra a Revolta de 1741, em Nova Iorque, mas mais do que isso, diz também respeito à transmissão circular da experiência humana. Os autores demarcam as docas e os bares ao redor como espaços de sociabilidade fundamentais, que proporcionaram a troca de experiência múltiplas e a formação de laços de solidariedade por motivo comum: a oposição à ordem colonial inglesa por meio do planejamento de uma revolta. Nesses espaços, marujos, soldados e escravos de origens diferentes - Caribe, várias regiões da África e Irlanda - foram unidos, cada um com suas peculiaridades e posições-de-sujeito, em uma narrativa relacional com os brancos ingleses, e assim representados como sujeitos inteiros, agentes de seus próprios destinos dentro da experiência da dominação.

Esse capítulo também atua descentrando a história por meio do seu deslocamento geográfico da Europa para o Atlântico. Nesse sentido, Natalie Davis afirma que é comum, em ordem de validar ou argumentar sobre um processo cultural ou político mais amplo - e, nesse caso, podemos citar os processos de circulação de conhecimentos e pessoas -, os historiadores selecionarem acontecimentos acontecidos no continente europeu; ou, ainda, selecionar a Europa como modelo comparativo para as demais regiões em categorias vagas e arbitrárias de progresso e atraso (DAVIS, 2011).

No entanto, o mundo é plural em experiências e pode-se buscar narrativas locais de outras partes do globo para se construir tal narrativa. Davis defende também uma história focalizada mais nas travessias culturais e fronteiras do que dentro das unidades nacionais. Essa postura prática dialoga positivamente com a cultura política da modernidade tardia e acredito poder ajudar no processo de democratização das representações históricas e, consequentemente, das identidades dos estudantes.

Em resumo, a contestação das identidades nacionais fixas pelos diversos movimentos sociais, associada à atualização historiográfica proporcionada pela Nova História Cultura e Política, vem abrindo novas possibilidades de referência, construção e apropriação do passado. Isso acontece porque a forma com a qual olhamos para o passado está muito calcada na forma com a qual vivenciamos o nosso presente. Esse olhar, assim, acaba dizendo mais sobre as posições-de-sujeito do presente do que sobre uma reafirmação de uma suposta verdade histórica. 
Exemplo desse processo é a reivindicação das pessoas negras por uma identidade calcada no resgate de um passado e uma cultura africana comuns ${ }^{33}$. Essa identificação cultural provém principalmente das regiões das quais o Brasil importou maior número de pessoas escravizadas - majoritariamente, mas não só, nos séculos XVIII e XIX -, atual região da Angola e da Nigéria, entendendo-se pela região que vai desde a África central ocidental até a oriental, principalmente em Moçambique. "Assim, essa redescoberta do passado é parte do processo de construção da identidade que está ocorrendo neste exato momento e que, ao que parece, é caracterizado por conflito, contestação e uma possível crise" (Woodward In: Silva, 2000, p. 12).

Embora essa nova apropriação do passado seja positiva, no sentido de colaborar para justamente quebrar a visão cultural europeia hegemônica e descentrar o conhecimento histórico, é preciso cuidado para que não se crie um novo essencialismo, igualmente falso, de um passado africano verdadeiro, que havia sido reprimido mas que agora finalmente foi "revelado". O conhecimento histórico é sempre construído por uma relação presente/passado, historiador/fonte, contexto/texto, devendo ser encarado como uma narrativa e não como um fato solidificado. "Isso não significa negar que a identidade tenha um passado, mas reconhecer que, ao reivindica-la, nós a reconstruímos e que, além disso, o passado sofre uma constante transformação" (Woodward In: Silva, 2000, p. 28).

No entanto, se o conhecimento histórico é construído por múltiplas narrativas socialmente formadas, ou seja, por diversas versões do passado, também corremos o risco de cair num relativismo vazio, no qual a diferença das versões seja comemorada igualmente, apenas em sua existência plural. Isso pode acabar apagando o elemento desigual das relações de poder, que abarca toda a estrutura social e forma hierarquias sociais identitárias, com manifestações tanto materiais quanto simbólicas.

As múltiplas identidades construídas pelas narrativas históricas devem ter, assim, suas diferenças de fato reconhecidas e salientadas, porém elas devem ser levadas em conta a nível relacional, sendo colocadas num contexto social de análise,

\footnotetext{
${ }^{33}$ Parto, para isso, do princípio de que o conceito de "raça" é discursivo, e não biológico, ou seja, reúne, segundo Hall, 2011, p. 63 e 64: "um conjunto frouxo, frequentemente pouco específico, de diferenças em termos de características físicas (...) como marcas simbólicas, a fim de diferenciar socialmente um grupo do outro".
} 
já que são cotidianamente vivenciadas na esfera coletiva da sociedade. Essa concepção de identidade cultural, segundo Hall, é aquela regida por um caráter performativo, por meio do verbo "tornar-se", mais que apenas por meio do verbo "ser", e conclui muito bem todo o pensamento até aqui elencado:

Ao ver a identidade como uma questão de "tornar-se", aqueles que reivindicam a identidade não se limitariam a ser posicionados pela identidade: eles seriam capazes de posicionar a si próprios e de reconstruir e transformar as identidades históricas, herdadas de um suposto passado comum (Woodward In: Silva, 2000, p. 28).

Parte do objetivo da história como disciplina escolar é, então, evidenciar as diferenças entre o passado e o presente, desmistificando o perene e, assim, elucidando o potencial transformador do ser humano. Creio ser a prática do multiculturalismo performativo, construído por meio de um discurso histórico escolar descentrado, capaz de sanar o perigo do relativismo vazio, bem como de oferecer as bases teóricas críticas para a elaboração de identidades cada vez mais centradas num processo de "tornar-se". As mudanças históricas, dessa forma, podem aparecer não mais como ameaças à coesão social, mas sim como qualidades humanas de amplo potencial performativo. 


\section{Conclusão}

No primeiro capítulo, chamado "O discurso histórico escolar", refleti sobre essa prática social à luz de várias contribuições teóricas. Para isso, primeiramente, fiz uso da interdisciplinaridade com outras ciências sociais - antropologia, filosofia, linguística - a fim de pensar sobre o conceito de "discurso", associando-o ao de cultura no que tange o caráter dual. O termo cultura implica uma relação dialética entre as estruturas simbólicas cognitivas e as práticas sociais contingenciais. Da mesma forma, o discurso, como sistema linguístico (estrutural) e acontecimento social (prática), guarda semelhantes características, sendo definido aqui, com base nos estudos de Fairclough, como prática social de construção de significado.

Também foi analisada a trajetória historiográfica de produção de conhecimento. $\mathrm{O}$ discurso histórico experimentou mudanças profundas desde o século XIX, que acompanharam as transformações mentais e materiais da sociedade, e sua forma de escrita e transmissão não poderiam se manter imóveis nesse processo cultural e político. Essas mudanças puderam aqui ser pensadas levando-se em conta as peculiaridades do ambiente escolar, tais como o processo de transposição didática do conhecimento e a função do professor como mediador deste último.

O trabalho de Foucault A Ordem do Discurso foi bastante relevante para este capítulo, pois nos ajudou a compreender de maneira mais nítida como as relações de poder se hierarquizam e se organizam dentro do tecido social, formando uma cultura política e atuando inclusive no ambiente escolar, tanto por meio da estruturação da instituição, quanto por meio da dominação das práticas discursivas. Nesse sentido, todo discurso, enquanto linguagem, carrega em si procedimentos e funções permeados por relações de poder e características inconscientes, mas ativas, que visam a manutenção ou a transgressão de discursos anteriores, sendo capaz de legitimar sistemas de dominação ou noções de verdade presentes na sociedade.

No segundo capítulo, me propus a explorar o conceito de identidade, termo chave para o presente trabalho, e mostrar sua inseparabilidade em relação ao conceito de diferença, formando um conjunto no qual um não poderia existir sem o outro. A seguir, centralizei a discussão em torno das representações, vistas como 
matérias-primas simbólicas de apreensão e construção de sentidos. É por meio delas, portanto, que os indivíduos efetuam seus múltiplos processos de identificação e subjetivação das categorias simbólicas culturais, sendo então conceito chave para todo o encadeamento argumentativo aqui estruturado.

Para esse capítulo, baseei-me principalmente em Stuart Hall e Tomaz Tadeu da Silva. Hall elabora no livro A identidade cultural na pós-modernidade um pensamento consistente sobre o conceito de identidade; afirma não ser algo inato, mas sim sempre em processo de descontinuidade. As identidades são construídas e desconstruídas por meio da interação e do diálogo e devem ser, portanto, associadas ao conceito de alteridade.

Pudemos, ademais, entender um pouco mais sobre o período atual de quebra de paradigmas e como ele afeta nossa percepção de si. A identidade social, antes vista como sólida e imutável no bojo da categoria nacional de construção de sentidos, agora se fragmenta em face à emergência de múltiplas formas de identificação, a nível local e pessoal, as quais podemos destacar aqui o gênero, a raça e a sexualidade. Isso significa que as diferenças sociais obscurecidas durante décadas estão agora reivindicando seu lugar de igual destaque ao lado da identidade nacional, antes suprema e unificadora, provocando justamente um deslocamento do nacional para o local, do unitário para o múltiplo.

Para ilustrar melhor o processo supracitado de conexão entre identidade e cidadania na contemporaneidade, e suas características fluidas e descontínuas, destaco pensamento de Luis Fernando Cerri, presente em seu livro Ensino de história e consciência histórica: implicações didáticas de uma discussão contemporânea:

Identidade e cidadania são, hoje, multidimensionais. Fatores como etnia, gênero, opção sexual ${ }^{34}$, religião e regionalismo interferem fortemente na constituição da identidade dos indivíduos e alternam-se, juntamente com a identidade política ou cidadania, no topo da hierarquia variável de pertencimentos que caracterizam o sujeito pós-moderno (Cerri, 2011, pp. 121).

Finalmente, no terceiro capítulo, concluí ser o discurso histórico escolar, enquanto objeto desta pesquisa, fundamental para a edificação de uma memória

\footnotetext{
${ }^{34}$ Saliento que a terminologia correta é orientação sexual.
} 
coletiva, que orienta posições-de-sujeito e comportamentos, assim como também direciona a construção das visões sobre si dos diversos atores sociais. Essas memórias tornam-se partes imprescindíveis para a formulação de projetos de futuro, tanto a nível pessoal, quanto a nível coletivo. Aqui o debate girou em torno principalmente de Gilberto Velho, Astor Antônio Diehl e Tomaz Thadeu da Silva. Como base teórica-conceitual concentrei-me nos estudos de Reinhart Koselleck a respeito das categorias históricas denominadas "espaço de experiência" e "horizonte de expectativa".

A cultura, em sua relação dual com a realidade, conferiu-se, nesta pesquisa, como elemento central para repensarmos as práticas sociais cotidianas e sua relação com as representações difundidas na multiplicidade de espaços de convivência, tais como a mídia, o lar, o ambiente profissional e, com mais relevância para nossa proposta aqui, a sala de aula. Como demonstrei, seu impacto simbólico é tangível e não deve ser menosprezado por uma concepção essencialista.

Sobre isso, a educadora Carmen Teresa Gabriel, no seu capítulo intitulado Conhecimento escolar, cultura e poder: desafios para o campo do currículo em "tempos pós" pode resumir a importância atrelada aqui ao conceito de cultura no discurso histórico escolar: "Operar com o conceito de cultura, nessa perspectiva, passa a ser uma condição de pensamento, um princípio orientador de leitura do mundo" (Gabriel. In: Moreira; Candau, 2008, p. 220).

Reconhecendo a importância e a problemática da difusão e reprodução de elementos representativos fora do ambiente institucional da escola, restringi-me ao âmbito da sala de aula pois acredito ser a aula de História ambiente propício e adequado para o debate e reflexão crítica sobre as construções identitárias; discussão essa geralmente ausente desses demais espaços de exposição e sociabilidade.

Se o objetivo da educação é a formação plena do cidadão, é necessário que este seja capaz de interiorizar criticamente as diversas representações pelas quais o mundo é construído e que saiba se posicionar nele historicamente. Uma vez consciente desse processo, é possível pensar em uma forma de discurso que resgate o caráter de acontecimento e possibilidade; que ao invés de determinista, seja crítico, reflexivo e plural, pois "produzir conhecimentos é operar no universo de significados" (Gabriel. In: Moreira; Candau, 2008, p. 227). 
Foi objetivo deste trabalho, por fim, mostrar como os docentes em formação ou em exercício podem assumir práticas sociais de cunho transformador, ao longo da atividade cotidiana do magistério, que almejem a desconstrução das interdições discursivas sofridas pelos grupos marginalizados ao longo da história; dar-lhes voz e autonomia.

Dessa forma, a proposta de intervenção do multiculturalismo performativo como caminho para a elaboração de uma narrativa histórica descentrada - fora dos sistemas binários de representação - parece ser coerente e urgente. Aposto ser ele capaz de fornecer subsídios para a elaboração de memórias individuais e coletivas que ofereçam a pluralidade como única constância da vida, permitindo a construção de identidades saudáveis.

Para além da tolerância e do respeito, as representações discursivas não podem ser tratadas ingênua e levianamente, devendo ser compreendidas como produções culturais e históricas. Acredito que o caminho não seja mais a harmonização dos conflitos sociais, mas a exposição e - o mais importante - a postura crítica atitudinal em relação a ele. A convivência íntegra e saudável com o diferente não pode ser negligenciada num sistema educacional e nacional que se afirme democrático. 


\section{Bibliografia}

BITTENCOURT, Circe. Ensino de História: Fundamentos e Métodos. São Paulo: Cortez, 2008

BRASIL, Diretrizes Curriculares Nacionais Gerais da Educação Básical Ministério da Educação. Secretária de Educação Básica. Diretoria de Currículos e Educação Integral. - Brasília: MEC, SEB, DICEI, 2013.

CERRI, Luís Fernando. Ensino de história e consciência histórica. Rio de Janeiro: Editora FGV, 2011.

CORDEIRO JUNIOR, R. B.; FLORES, E. C.; CURY, C. E. Cultura histórica e historiografia: legados e contribuições do século 20. João Pessoa: Ed. UFPB, 2010.

DAVIS, Natalie Z. Descentering history: local stories and cultural crossings in a global world. History and Theory, 50, may 2011, p. 188-202.

DIEHL, Astor Antônio. Cultura historiográfica: memória, identidade e representação. Bauru, SP: EDUSC, 2002.

FAIRCLOUGH, Norman; MAGALHÃES, Izabel. Discurso e mudança social. Brasília, DF: Ed. Universidade de Brasília, 2001, 316 p.

FONSECA, Thais Nivia de Lima e. História \& ensino de História. 4.ed. Belo Horizonte: Autêntica Editora, 2017.

FOUCAULT, Michel. A ordem do discurso: aula inaugural no Collège de France. São Paulo: Edições Loyola, 24. ed, 2014.

GONTIJO, R.; SOIHET, R.; ABREU, M. Cultura política e leituras do passado: historiografia e ensino de história. Rio de Janeiro: Civilização Brasileira, 2007.

GOUVÊA, M. De F.; BICALHO, M. F. B.; SOIHET, R. Culturas políticas: ensaio de história cultura, história política e ensino de história. Rio de Janeiro: FAPERJ: Mauad, 2005.

HALL, Stuart. A identidade cultural na pós-modernidade. 11. ed. Rio de Janeiro: DP\&A, 2006. 
KOSELLECK, Reinhart. Futuro passado: contribuição à semântica dos tempos históricos. Rio de Janeiro: Contraponto: Ed. PUC-Rio, 2006.

LIMA, Maria. "Consciência Histórica e educação histórica: diferentes noções, muitos caminhos" In: MAGALHÃES, Marcelo, [et al] (org.). Ensino de história: usos do passado, memória e mídia. Rio de Janeiro: Editora FGV, 2014, p. 53-76.

LINEBAUGH, Peter e REDIKER, Marcus. A hidra de muitas cabeças: marinheiros, escravos, plebeus e a história oculta do Atlântico revolucionário. São Paulo: Companhia das letras, 2008 [2001].

MAGALHÃES, Marcelo, [et al.] (org.). Ensino de história: usos do passado, memória e mídia. Rio de Janeiro: Editora FGV, 2014.

MONTEIRO, Ana Maria. "Os saberes que ensinam: o saber escolar" In:

Professores de História: entre saberes e práticas. Rio de Janeiro: ed. Mauad X, 2007, cap. 3, p. 81-111.

MOREIRA, Antonio Flávio; CANDAU, Vera Maria (orgs.). Multiculturalismo: diferenças culturais e práticas pedagógicas. Petrópolis, RJ: Vozes, 2008

MORETTO, Vasco Pedro. Construtivismo: a produção do conhecimento em aula. 3. ed. Rio de Janeiro: DP\&A, 2003.

RIBEIRO, Djamila. O que é lugar de fala?. Belo Horizonte: Letramento: Justificando, 2017.

SAHLINS, Marshall. Ilhas de história. Rio de Janeiro: J. Zahar, 1990.

SILVA, Tomaz Tadeu da Silva (org.); HALL, Stuart; WOORWARD, Kathryn. Identidade e diferença: a perspectiva dos estudos culturais. Petrópolis, RJ: Vozes, 2000.

SLENES, Robert. "Eu venho de muito longe, eu venho cavando": jongueiros cumba na senzala centro-africana, In: LARA, Silva e PACHECO, Gustavo (orgs.). Memória do Jongo. Rio de Janeiro: Folha Seca, 2007.

VELHO, Gilberto. Projeto e metamorfose: antropologia das sociedades complexas. 2.ed. Rio de Janeiro: Ed. Jorge Zahar, 1999. 